\title{
Does intra-ruminal nitrogen recycling waste valuable resources? A review of major players and their manipulation
}

\author{
Thomas Hartinger, Nina Gresner and Karl-Heinz Südekum ${ }^{*}$ (1]
}

\begin{abstract}
Nitrogenous emissions from ruminant livestock production are of increasing public concern and, together with methane, contribute to environmental pollution. The main cause of nitrogen-(N)-containing emissions is the inadequate provision of $\mathrm{N}$ to ruminants, leading to an excess of ammonia in the rumen, which is subsequently excreted. Depending on the size and molecular structure, various bacterial, protozoal and fungal species are involved in the ruminal breakdown of nitrogenous compounds (NC). Decelerating ruminal NC degradation by controlling the abundance and activity of proteolytic and deaminating microorganisms, but without reducing cellulolytic processes, is a promising strategy to decrease $N$ emissions along with increasing $N$ utilization by ruminants. Different dietary options, including among others the treatment of feedstuffs with heat or the application of diverse feed additives, as well as vaccination against rumen microorganisms or their enzymes have been evaluated. Thereby, reduced productions of microbial metabolites, e.g. ammonia, and increased microbial $\mathrm{N}$ flows give evidence for an improved $\mathrm{N}$ retention. However, linkage between these findings and alterations in the rumen microbiota composition, particularly NC-degrading microbes, remains sparse and contradictory findings confound the exact evaluation of these manipulating strategies, thus emphasizing the need for comprehensive research. The demand for increased sustainability in ruminant livestock production requests to apply attention to microbial $\mathrm{N}$ utilization efficiency and this will require a better understanding of underlying metabolic processes as well as composition and interactions of ruminal NC-degrading microorganisms.
\end{abstract}

Keywords: Ammonia, Bacteria, Deamination, Hyper-ammonia producing, Nitrogen efficiency, Protein, Proteolysis, Protozoa, Ruminant

\section{Background}

Understanding the rumen metabolism is of central importance $[1,2]$ and a prerequisite to meet the animal's requirements for nutrients and energy. The rumen microbiota constitutes a complex ecosystem, the metabolic activity of which is responsible for rumen metabolism, including intra-ruminal $\mathrm{N}$ recycling [3]. Thus, it is a key factor that needs to be taken into consideration when a sustainable and efficient livestock production is pursued. Rumen microbiota-related studies have so far focused on cellulolytic microorganisms, their metabolic pathways and how to optimize ruminal fiber degradation $[4,5]$. However, in the rumen, the vast majority of dietary crude protein is microbially degraded to ammonia

\footnotetext{
* Correspondence: ksue@itw.uni-bonn.de

Institute of Animal Science, University of Bonn, 53115 Bonn, Germany
}

[6], which constitutes the main and sometimes even sole $\mathrm{N}$ source for rumen microorganisms [7]. Excessive ruminal proteolysis and deamination cause inordinate amounts of ammonia, which are absorbed by the ruminant, converted to urea and subsequently predominantly excreted via the urine, leading to increased environmental pollution [8] and poor amino acid (AA) supply to the host. Hence, an efficient utilization of crude protein should be aimed at; also, to ensure the maximum retention of $\mathrm{N}$, knowledge of ruminal NC-degrading microorganisms is indispensable [9].

Research on the abundance, composition and metabolism of NC-degrading microorganisms is particularly needed for developing strategies to cope with the challenge of finding the optimal balance between the inhibition of ruminal NC degradation, without compromising 
post-ruminal AA absorption, and the simultaneous provision of appropriate amounts of $\mathrm{N}$ for the rumen microbiota. Improvements in techniques for studying microbial communities already allow the broad use of culture-independent techniques [10], which enable a more comprehensive characterization of the rumen microbiota compared to cultivation [11]. Omics-based approaches and quantitative real-time polymerase chain reaction (qPCR) assays have markedly enhanced our understanding of the rumen microbiota and are inevitable for the investigation of NC-degrading microorganisms. In particular, when omics methods are combined to analyze not only the abundance and diversity of genes, but also functional compositions as well as protein and metabolite profiles, a deeper knowledge will be obtained [10]. However, as omics approaches are not sufficient to target microorganisms on a species level [12] or to determine absolute abundances [13], qPCR represents an indispensable tool for the investigation of single microbial key species of ruminal NC degradation [8, 14].

The present review represents a starting point and aims to encourage research targeting the lack of knowledge of NC-degrading microorganisms, thereby developing and optimizing strategies for manipulating them. To give a critical status quo on this topic, existing information on the activity and abundance of rumen microorganisms involved in the degradation of proteins, peptides, AA and urea, as well as their principal interactions, is briefly summarized in the first part of this review. So far, this information is limited and needs expansion by state-of-the-art technologies regarding all aspects of the rumen microbiome, i.e. genome, transcriptome, proteome and metabolome, finally leading to a better understanding of both, its structure and its function. Thereby, functional characterization by omics addressing also uncultivable microorganisms will expand our current knowledge on NC-degrading microbes that was generated predominantly by cultivation and enzymatic activity tests. The second review part will cover options that have been considered so far to influence NC-degrading microorganisms by dietary factors as well as vaccination. Here, we based our review on a systematic literature search, as the high diversity in experimental conditions and applied techniques between the contemplated studies make a meta-analysis inappropriate.

\section{Ruminal microorganisms involved in the degradation of nitrogenous compounds}

Rumen microbes are supplied with NC by the diet and with that mainly as proteins, peptides and AA. In addition to the potential provision of urea by feed $[6,15]$, endogenous urea is supplied to the rumen via the rumino-hepatic circulation [16]. Depending on NC, different ruminal microorganisms are involved in their breakdown (Table 1) and synergistic microbial enzyme activities are often required for the complete degradation of $\mathrm{NC}$ to ammonia $[17,18]$ (Fig. 1). However, one has to emphasize that published studies quantifying the abundances of microorganisms are very heterogenic in their sampling, as well as quantification methods, thus complicating their comparison. High standardization of experimental conditions help to diminish this problem and should be considered in future study designs. As bacterial, protozoal and fungal cells contain different copy numbers of $16 \mathrm{~S}$ rDNA, 18S rDNA or internal transcribed spacer 1, respectively [19-21], it is particularly difficult to put data from culture-independent approaches in relation to earlier results obtained from cultivation. Moreover, culture-independent techniques allow species-specific identification, but rumen microorganisms are often only characterized on a genus level, e.g. Prevotella by Deckardt et al. [22]. Due to the great heterogeneity within one genus [23], the interpretation of such results becomes even more challenging and a considerable part of the potentially acquired information is easily lost.

\section{Bacteria \\ Proteolytic bacteria}

Bacteria represent the most abundant domain in the rumen [24] and are present in numbers of $10^{10}-10^{12}$ cells/g rumen content $[2,11]$. In cattle, using rRNAtargeted oligonucleotide probes, Lin et al. [25] assigned $60-84 \%$ of total rRNA to this domain, while Prins et al. [18] had previously assigned $65 \%$ of ruminal proteolytic activity to bacteria, which underlines their involvement in NC degradation.

Two important key species for protein degradation belong to the highly abundant genus Butyrivibrio [24], namely Butyrivibrio fibrisolvens [26] and B. proteoclasticus [27]. They are present in ruminant species across all continents [24] and exert high proteolytic activities [27-29]. The increased number of $16 \mathrm{~S}$ rDNA copies of $B$. fibrisolvens when protein supply to dairy cows was increased [30] may confirm its role in protein metabolism, and in sheep B. fibrisolvens and $B$. proteoclasticus accounted for approximately $4.2 \%$ and $4.0 \%$ of total $16 \mathrm{~S}$ rDNA copies, respectively [31]. Besides proteolysis, B. fibrisolvens is also involved in fiber degradation [32]. The results of Vasta et al. [31] regarding the abundance of $B$. proteoclasticus are in accordance with qPCR data from Paillard et al. [14], whereas Reilly et al. [33] observed B. proteoclasticus to represent $2.01 \times 10^{6} / \mathrm{mL}$ to $3.12 \times 10^{7} / \mathrm{mL}$, which corresponds to only $0.3 \%$ of the bacterial population [14]. This could be due to differences in fed diets [24]; however, the application of different primers or DNA extraction procedures can also cause diverse results $[34,35]$. In this context, "a universal extraction method with equally efficient lysis of cell walls of all possible microorganisms" [36] is essential to obtain comparable results and calls 
Table 1 Overview of microorganisms involved in the ruminal degradation of proteins, peptides, AA and urea $^{a}$

\begin{tabular}{|c|c|c|c|c|c|c|}
\hline Group & Microbial species & Proteins & Peptides & AA & Urea & Reference \\
\hline \multirow[t]{30}{*}{ Bacteria } & Allisonella histaminiformans & & & $x$ & & {$[72,73]$} \\
\hline & Butyrivibrio fibrisolvens & $x$ & & $x$ & & {$[26,69]$} \\
\hline & Butyrivibrio proteoclasticus & $x$ & & & & [27] \\
\hline & Clostridium sp. & & & $x$ & & [77] \\
\hline & Clostridium aminophilum & & & $x$ & & [77] \\
\hline & Clostridium sticklandii & & & $x$ & & [77] \\
\hline & Eubacterium sp. & $x$ & & $x$ & & {$[47,69]$} \\
\hline & Eubacterium budayi & $x$ & & & & [27] \\
\hline & Eubacterium pyruvativorans & & & $x$ & & [82] \\
\hline & Eubacterium ruminantium & & $x$ & & & [53] \\
\hline & Fibrobacter succinogenes & & $x$ & & & [53] \\
\hline & Fusobacterium sp. & $x$ & & & & [26] \\
\hline & Howardella ureilytica & & & & $x$ & [91] \\
\hline & Klebsiella aerogenes & & & & $x$ & [88] \\
\hline & Lachnospira multipara & $x$ & $x$ & & & {$[49,53]$} \\
\hline & Lactobacillus casei var. casei & & & & $x$ & [88] \\
\hline & Micrococcus varians & & & & $x$ & [89] \\
\hline & Megasphaera elsdenii & & $x$ & $x$ & & [53] \\
\hline & Peptostreptococcus anaerobius & & & $x$ & & [77] \\
\hline & Prevotella sp. & $x$ & $x$ & $x$ & & {$[54,70]$} \\
\hline & Prevotella albensis & $x$ & $x$ & & & {$[39,61]$} \\
\hline & Prevotella brevis & $x$ & $x$ & & & [52] \\
\hline & Prevotella bryantii & $x$ & $x$ & & & [52] \\
\hline & Prevotella ruminicola & $x$ & $x$ & $x$ & & {$[51,70]$} \\
\hline & Ruminobacter amylophilus & $x$ & & & & [28] \\
\hline & Selenomonas ruminantium & $x$ & & $x$ & $x$ & {$[15,42,69]$} \\
\hline & Staphylococcus sp. & & & & $x$ & [88] \\
\hline & Staphylococcus saprophyticus & $x$ & & $x$ & $x$ & [89] \\
\hline & Streptococcus bovis & $x$ & $x$ & $x$ & & {$[27,53,69]$} \\
\hline & Streptococcus faecium & & & & $x$ & [88] \\
\hline \multirow[t]{10}{*}{ Protozoa } & Dasytricha sp. & $x$ & & & & [96] \\
\hline & Dasytricha ruminantium & $x$ & $x$ & & & {$[94,104]$} \\
\hline & Entodinium spp. & $x$ & $x$ & & & {$[103,104]$} \\
\hline & Entodinium caudatum & $x$ & & $x$ & & [103] \\
\hline & Entodinium simplex & $x$ & & & & {$[96,103]$} \\
\hline & Epidinium sp. & $x$ & & & & [96] \\
\hline & Epidinium caudatum ecaudatum & $x$ & & & & {$[94,96,104]$} \\
\hline & Isotricha spp. & $x$ & $x$ & & & {$[94,96]$} \\
\hline & Ophryoscolex caudatus & $x$ & & & & [94] \\
\hline & Polyplastron multivesiculatum & $x$ & & & & [94] \\
\hline \multirow[t]{4}{*}{ Fungi } & Neocallimastix frontalis & $x$ & $x$ & & & {$[114,118]$} \\
\hline & Neocallimastix patriciarum & $x$ & & & & [116] \\
\hline & Orpinomyces joyonii & $x$ & & & & [116] \\
\hline & Piromyces sp. & $x$ & $x$ & & & [118] \\
\hline
\end{tabular}


Table 1 Overview of microorganisms involved in the ruminal degradation of proteins, peptides, AA and urea ${ }^{\text {(Continued) }}$

\begin{tabular}{lllllll}
\hline Group & Microbial species & Proteins & Peptides & AA & Urea & Reference \\
\hline & Piromyces communis & $\mathrm{X}$ & & & \\
\hline
\end{tabular}

${ }^{a}$ Without consideration of detection method, quantity of substrate degradation or impact on ruminal $\mathrm{N}$ metabolism

for mandatory bead beating, particularly as the rumen harbors various hard-to-lyse bacteria [37].

Streptococcus bovis expressed extracellular proteases $[26,27,29,38]$ and high proteolytic activity in the presence of several proteins [38, 39]. According to Attwood et al. [27], Strep. bovis may be particularly significant for ruminal proteolysis in grazing ruminants due to the semi-continuous grazing pattern and high protein contents of pasture, which would provide unique conditions, enabling this species to become a dominate proteolytic bacterium. Nevertheless, Strep. bovis can be absent from the rumen [40] or account for only $0.5-1.6 \%$ of the ruminal bacterial DNA [30]. However, low abundant microorganisms can also exert high enzymatic activities
[41] and are therefore essential for ruminal protein metabolism. Besides protein degradation, Strep. bovis degrades starch for glucose fermentation and exerted proteolytic activity independent of the available $\mathrm{N}$ source, which led to the hypothesis that Strep. bovis degrades protein not only for subsequent $\mathrm{N}$ utilization, but mainly to break down protein matrices, surrounding starch granules [38].

Other bacteria involved in ruminal protein degradation are Selenomonas ruminantium [42] and Ruminobacter amylophilus [28], although both show low abundance when quantified via quantitative fluorescence in situ hybridization in cattle [43] or qPCR in sheep [44] and cattle [45]. However, despite its low abundance, $R b$.

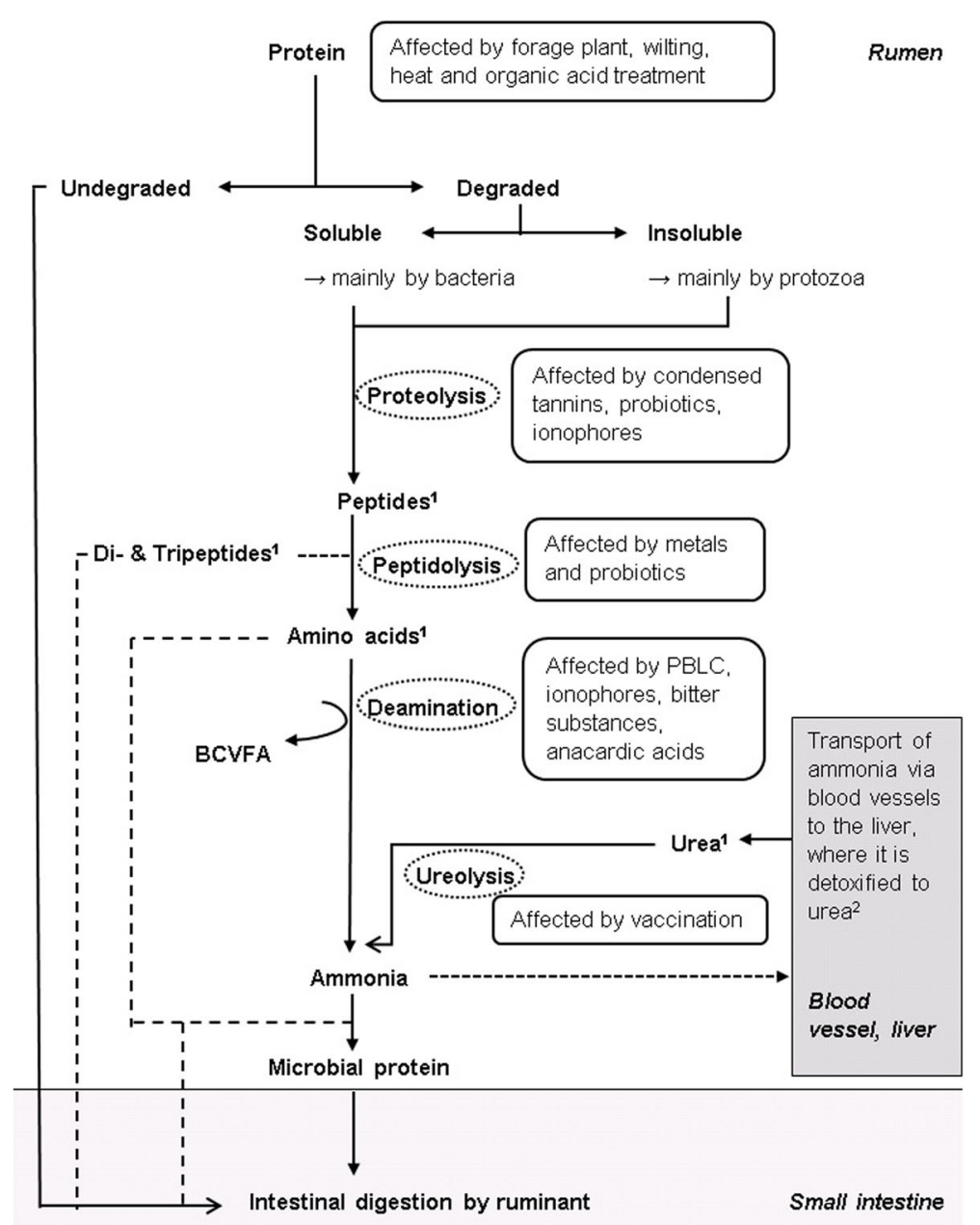

Fig. 1 Simplified scheme of intestinal N metabolism and the target sites of manipulation strategies for reducing ruminal NC degradation that have shown effectiveness in vivo or in vitro (according to $[6,22,86,87,102,138,151,155,156,160,166,168,202,208,218]$ ). ${ }^{1}$ This NC can also be supplied with the feed; ${ }^{2}$ Urea is partly excreted with urine 
amylophilus is assumed to be a highly proteolytic bacterium of the rumen microbiota [46] and showed higher azocasein degradation rates than some $B$. fibrisolvens strains [28]. Species of Eubacterium, especially Eubacterium budayi [27], are further active protein degraders [47] and Eubacterium contributed 16\% to total proteolytic activity in the rumen [27]. Analyzing ruminal bacteria by competitive PCR in dairy cows, Reilly et al. [47] found that approximately $0.3-0.9 \%$ of bacterial cells belonged to Eubacterium. Also, Fusobacteria have high proteolytic activities [26], but their contribution to ruminal protein degradation in high-yielding dairy cattle may be limited as next-generation sequencing (NGS) obtained no Fusobacterium sp. in heifers fed high-grain diets [48].

Several species of Prevotella are crucial for hydrolyzing dietary protein in the rumen [49]. For example, P. albensis exerted proteolytic activity when incubated with varying concentrations of casein [39]. Thereby, it had a lower specific proteolytic activity than Strep. bovis, but as Prevotella is highly abundant in the rumen [24, 50], the contribution of $P$. albensis to ruminal proteolysis is substantial [39]. Further studies showed that strains of $P$. ruminicola [51], P. brevis and, to a smaller extent also $P$. bryantii, possessed proteolytic activities [28, 52]. However, Prevotella is even more important in the subsequent degradation of peptides $[53,54]$ and will therefore be considered again in the following section.

Finally, there are various rumen bacteria with minor proteolytic activities [26, 42], e.g. Lachnospira multipara [49]. However, these microbes may be relevant for overall proteolytic capacity in the rumen, especially as they can have nutritional interdependences with highly proteolytic species [42].

\section{Peptidolytic bacteria}

Peptides originating from the diet or ruminal proteolysis are mainly degraded by members of the rumen microbiota. As found for protease activity [18], peptidase activity is also predominantly of bacterial origin [54].

Prevotella represents a highly abundant genus in the rumen $[24,55]$ and was observed to have a broad peptidolytic activity $[53,54]$ with high peptidase diversity as recently obtained from metagenomic sequence data [56]. Stevenson et al. [57] observed that Prevotella spp. were highly abundant in the rumen of lactating cows and accounted for $42-60 \%$ of total eubacterial rDNA copies. Although Prevotella primers from [57] were later found to match numerous non-Prevotella species [58], the results are in the same range observed by NGS, i.e. $52 \%$ of all reads [55]. On a species level, van Gylswyk [49] stated that $P$. ruminicola accounted for up to $60 \%$ of total rumen flora when cultivating bacteria from rumen ingesta on several media. Although $P$. ruminicola is a predominant microbe in the rumen [59], this abundance should be overestimated, as cultivation can produce biased results, e.g. due to cells that are in a viable but non-culturable condition [60]. Culture-independent approaches quantified the classical members $P$. bryantii, $P$. brevis and $P$. ruminicola to be $2-5 \%$ relative sequence abundance [57]. The exceptionally huge deviation in the abundance of $P$. ruminicola between these studies must be considered critically as it barely represents normal variation between different rumen microbiota. Therefore, the ruminal abundance of specific Prevotella species demands further elucidation.

By expressing several peptidases with different substrate specificities [54, 61], P. albensis constitutes a central peptidolytic species in the rumen and pure cultures of $P$. albensis and P. bryantii expressed peptidase activities higher than or similar to those of rumen fluid when incubated with several peptides [53, 62]. In addition, several Prevotella species are potent carbohydrate degraders harboring a variety of CAZymes [63].

Although Megasphaera elsdenii lacks peptidase activity [64], this species expresses high dipeptidase activity [53]. Thus, M. elsdenii is substantial for the sufficient breakdown of dipeptides to AA in the rumen, especially in the case of protozoa being absent as they suppress the growth of M. elsdenii [53]. Concerning the abundance of M. elsdenii, there is a high inter-individual variation between ruminants [50], with $M$. elsdenii not being detected by qPCR in steer rumen samples in some studies [40,65]. However, just as many qPCR-based studies identified this species in the rumen of steers [66], dairy cattle $[30,67]$ and in vitro systems inoculated with bovine rumen fluid [8, 22, 68]. Ruminobacter amylophilus and Strep. bovis, as well as Lachnospira multipara, Fibrobacter succinogenes and Eu. ruminantium, express weak peptidolytic activities [53], but their contribution to ruminal peptidolysis appears marginal.

\section{Deaminating bacteria}

Only a small amount of AA is directly utilized for microbial protein synthesis. The bulk is deaminated, with volatile fatty acids, ammonia, carbon dioxide and methane being the end-products [6]. Total ruminal deamination is the result of a broad microbial activity, as no microorganism degrades all AA, but each prefers certain ones [69].

In 1961, Bladen et al. [70] stated that predominant bacteria with low ammonia production rates were the main ammonia producers in the rumen. However, as several studies have observed low abundant bacteria with high deaminating capacity [71], it is assumed that ruminal AA deamination is performed by two bacterial fractions: the first one constitutes bacteria present in a high number with low or moderate deaminating activity of 
about $10-20 \mathrm{nmol}$ ammonia/min/mg protein [41]. This fraction includes Butyrivibrio fibrisolvens and P. ruminicola, which underlines their central role in ruminal $\mathrm{N}$ metabolism, as well as M. elsdenii [64, 70]. Although strains of $M$. elsdenii vary significantly in their deamination capacity, some possess ammonia production rates which are comparable to the hyper-ammonia producing bacteria (HAB) [64], belonging to the second fraction of deaminating bacteria in the rumen. Also, Allisonella histaminiformans has the ability to decarboxylate histidine, which results in the formation of histamine and small amounts of ammonia [72]. However, it is questionable whether Allisonella histaminiformans is part of the native ruminal microbiota as results on its presence are inconsistent [72-75].

The second fraction of deaminating rumen microorganisms are bacteria present in a low number which exert high deaminating activities of more than $300 \mathrm{nmol}$ ammonia/min/mg protein [41]. These microbes are designated as $\mathrm{HAB}$. Due to their high deaminating rates, they are of particular relevance for intra-ruminal $\mathrm{N}$ recycling [71]. Although ammonia is an essential $\mathrm{N}$ source for cellulolytic rumen microbes [7], an oversupply of ammonia may be the result of the high deamination by $\mathrm{HAB}$, leading to poor ruminal $\mathrm{N}$ utilization efficiency and significant $\mathrm{N}$ losses [8]. By deaminating AA that could have stimulated the growth and therefore the ammonia utilization of the non-HAB majority [76], $\mathrm{HAB}$ might further reduce $\mathrm{N}$ utilization efficiency in the rumen.

Paster et al. [77] identified Clostridium aminophilum, $\mathrm{Cl}$. sticklandii and Peptostreptococcus anaerobius as $\mathrm{HAB}$, although they were already isolated earlier as strain F, strain SR [71] and strain C [78], respectively. Each of these three 'classical' HAB species had an abundance of $10^{7}$ cells $/ \mathrm{mL}$ rumen fluid [41] or, by applying $16 \mathrm{~S}$ rRNA hybridization, made up approximately $1 \%$ of total bacteria in the rumen [79]. However, other studies found these $\mathrm{HAB}$ to enumerate $5.2 \%$ and even $11.6 \%$ of total bacterial counts in cows and sheep, respectively [80]. Besides, Rychlik et al. [81] predicted HAB populations to be 4-fold higher in cattle fed hay compared to grain-fed cattle. Aside from their ionophore sensitivity, the ability to use AA as sole carbon, $\mathrm{N}$ and energy source is characteristic for HAB. They are unable to hydrolyze proteins and thus rely on peptide- and AAreleasing microorganisms [80]. According to Wallace et al. [82], Eu. pyruvativorans can be classified as HAB, although it grew poorly on free AA. In fact, Eu. pyruvativorans seems to prefer pyruvate as an energy source, because pyruvate is extracellularly rare in the rumen, AA utilization may be the fermentative niche of this bacterium [82].

So far, it was assumed that HAB were unable to ferment carbohydrates [80], but recent findings provide information on another type of HAB. In the rumen of steers, Bento et al. [83] observed bacterial isolates with ammonia production as high as 'classical' HAB [77], but with the ability to ferment carbohydrates, consequently disproving the assumption that carbohydrate-fermenting bacteria would only produce low amounts of ammonia [70, 81]. These 'new' HAB isolates [83] might not have been recognized, as $\mathrm{HAB}$ were often isolated on selective media in the past, with AA being the sole carbon source [78]. However, this does not mean that they all can only ferment AA, but have a wider metabolic role. Although phylogenetically distinct from the 'classical' rumen $\mathrm{HAB}$ [77], HAB with carbohydrate-fermenting activity are also present in swine manure and showed significantly less ammonia production when incubated with glucose, thus probably demonstrating a shift in biochemical pathways [84]. It may be possible that ruminal HAB isolates with carbohydrate-fermenting activity [83] can also shift between carbohydrate and AA utilization and would therefore have an advantage at energy generation compared to 'classical' HAB [77].

The 'new' HAB [83] were mainly assigned to Clostridiales, and isolates were closely related to $\mathrm{Cl}$. bifermentans, $C l$. argentinense or even 'classical' HAB $[77,83]$. Therefore, the genus Clostridium seems to harbor more HAB species that remained unknown to date. Other studies indicate the presence of HAB in the genera Fusobacterium, Eubacterium [80], Acidaminococcus and Desulfomonas [85]. To the best of our knowledge, no reports exist on the identification of HAB species in these genera. Research on the isolation and comprehensive metabolic characterization of further $\mathrm{HAB}$ is required, in particular studies confirming the existence of carbohydrate-fermenting HAB in the rumen.

\section{Ureolytic bacteria}

Urea constitutes a NC that is rapidly degraded by ruminal microorganisms and thus increases the ammonia pool in the rumen [86]. Depending on dietary composition, urea can constitute a part of the diet and therefore enters the rumen by feed intake $[6,15]$. Typically, however, urea originates from the rumino-hepatic circulation and is brought into the rumen via saliva or diffusion through the rumen wall $[87,88]$. This process may be useful under N-limiting conditions [87, 89], but when ruminants receive diets moderate or high in crude protein, the ammonia originating from ureolysis mainly returns to the blood rather than mixing with the rumen fluid and will be excreted into the environment [90].

Using cultivation-based techniques, several bacterial genera and species exerting ureolytic activity have been identified in the rumen, e.g. different strains of Staphylococcus sp., Lactobacillus casei var. casei, Klebsiella aerogenes and Strep. faecium with urease activities being either intracellular or linked to cell surface. Among these 
species, Strep. faecium showed the highest urease activity and was the most abundant of the isolated species [88]. Howardella ureilytica hydrolyzing urea for ATP generation was isolated from ovine rumen fluid [91] and strains of Staph. saprophyticus and Micrococcus varians were also isolated from sheep rumen and showed ureolytic activity during incubation with different NC. Besides, the majority of Staph. saprophyticus strains hydrolyzed casein and deaminated several AA [89], probably contributing to the overall proteolytic and deaminating activity in the rumen. With an abundance of at least $2 \times$ $10^{7} / \mathrm{mL}$, a ureolytic strain of Sel. ruminantium was isolated from bovine rumen [15]. Despite all these observations, the majority of ureolytic microbes are yet to be identified. Investigating the diversity of urease gene ureC in rumen fluid, digesta and papilla by NGS revealed that on average $55 \%$ of total sequences could not be assigned to any phylum. Most of these unknown sequences were found in the rumen papilla samples, where the ureolytic bacterial profile also clearly differed from those in digesta and fluid [92].

Research that considers all sampling sites in the rumen applying culture-independent methods like NGS are demanded as only limited knowledge on ureolytic rumen bacteria exists to date. However, cultivation will still be needed to definitely confirm ureolytic properties predicted with nucleic acid-based approaches [93]. Interestingly, this might be problematic as despite previous isolates being facultative anaerobes and their growth being virtually unaffected by oxygen, a considerable part of them lost the ability to undergo ureolysis during aerobic subculturing $[88,89]$.

\section{Protozoa}

In addition to bacteria, protozoa represent an important part of NC-degrading microorganisms in the rumen [94]. As described by Hungate [3], protozoa are eukaryotes and mainly present in the fluid phase, though they are chemoattracted to released nutrients [95] and thus some species are transiently attached to feed particles. Rumen protozoa enumerate approximately $10^{6}$ protozoal cells/mL rumen fluid [96]. Estimates of protozoal abundances using microscopy can cause misidentification coupled with a low sensitivity [97]. Thus, quantification by molecular techniques targeting the $18 \mathrm{~S} \mathrm{rDNA}$ may be better suited, but variation in $18 \mathrm{~S}$ rDNA copies between protozoal genera or different growth conditions can interfere [19]. Also, smaller protozoa were underrepresented by $18 \mathrm{~S}$ rDNA copies when comparing NGS data to protozoal counts [98], which demonstrates that NGS is superior for community structure analysis, but not precise quantification. In this context, an even more severe and general problem may be the procedure for obtaining protozoa samples. It was earlier shown that especially large protozoa are more retained by feed particles when rumen fluid is filtered through cheesecloth [99], which consequently leads to an overestimation of their abundance. Likewise, sedimentation funnels might not only concentrate protozoa, but also cause bias when some species are attracted to the funnel glass or do not sediment well. Thus, hereinafter mentioned abundances should be regarded with some reservations and may better serve as indications.

Protozoa are regarded as detrimental for ruminal N metabolism as they predate bacteria [96] or fungi [100] and large protozoa also engulf smaller protozoa [101], which altogether reduces ruminal $\mathrm{N}$ utilization efficiency. Protozoa also degrade feed protein, particularly insoluble particles [102] and thereby significantly contribute to ruminal dietary protein degradation [94]. Prins et al. [18] emphasized their role in ruminal protein breakdown as almost $20 \%$ of the proteolytic activity in rumen fluid is derived from protozoa. In contrast to $\mathrm{NC}$-degrading bacteria, on a species level, little is known about protozoa or their $\mathrm{N}$ metabolism, which demands for investigating these microbes in detail. The highest proteolytic activity was found in vitro for Entodinium caudatum and En. simplex [103], with inter-species differences in the expressed protease profiles [94]. Of all rumen protozoa, cellulolytic protozoa, in turn, exerted the lowest proteolytic activity [103]. According to protozoal fractionation and NGS, the genus Entodinium is predominant in cows with En. caudatum and En. simplex, both accounting for $0.5 \%$ of protozoal cells $[24,96]$.

Also Dasytricha ruminantium is highly proteolytic [94] and accounted for up to $34 \%$ of protozoal cells obtained from sedimentation funnels. It thus may have a great influence on both dietary protein degradation and the turnover of bacteria [96]. Furthermore, Polyplastron multivesiculatum exerted moderate proteolytic activity [94] and can account for $10-20 \%$ of the total protozoal population [102]. Members of Isotricha as well as Ophryoscolex caudatus showed less proteolytic activity, whereas that of Epidinium caudatum ecaudatum was higher [94, 102].

Protozoa also degrade dipeptides and Entodinium species exerted high dipeptidase activity, followed by $D$. ruminantium and members of Isotricha [104]. Therefore, protozoa also play a relevant role in the final stages of peptide catabolism. In a more recent study, isotrichids and entodiniomorphids showed chemotaxis towards bacterial, protozoal and soy peptides [105], which thereby indicated protozoal contribution in the ruminal breakdown of polypeptides [106].

Very little is known about deamination by ruminal protozoa [106]. Species of Entodinium showed deamination activity, although the quantity is negligible [107]. Hino et al. [16] observed deamination in ruminal 
protozoa mainly consisting of entodiniomorphids, and Forsberg et al. [108] also described low deaminase activity in protozoa sampled from rumen-cannulated cows. Concerning ureolysis, no urease activity was detected in protozoa [88, 107].

When concentrating on their contribution to ruminal $\mathrm{N}$ metabolism, protozoa have an adverse effect and reduce ruminal $\mathrm{N}$ utilization efficiency. However, parts of the protozoal population are also important for fiber degradation [109]; due to their ability to temporally incorporate starch granules, which are consequently not metabolized to organic acids, they prevent extensive $\mathrm{pH}$ drops and thus support a stable fermentation [110]. Finally, in consideration of a representative sampling, there is an urge to obtain deeper knowledge on the NC-degrading activity of ruminal protozoa on a species level to be able to diminish detrimental effects on ruminal $\mathrm{N}$ turnover.

\section{Fungi}

Fungi constitute about $10 \%$ of microbial biomass in the rumen [111] and are crucial fiber degraders [112], especially when forages with poor quality are fed to ruminants $[100,112]$. Generally, there is only marginal information on metabolic activities of rumen fungi [113] and consequently also on their contribution to NC degradation.

The fungus Neocallimastix frontalis PNK2, which was isolated from sheep rumen, showed high extracellular proteolytic activity, probably necessary for degrading structural proteins and for sufficient fiber degradation. Moreover, it was considered possible that proteases could modify activation of other fungus-derived CAZymes [114]. In vitro, proteolytic activity of solid rumen ingesta was considerably increased in the presence of this fungal strain [115]. Thus, the authors assumed proteolytic fungi to play an important role in ruminal protein degradation [114, 115]. Also, the ruminal fungi Ncm. patriciarum, Orpinomyces joyonii and Piromyces communis showed proteolytic activities during incubation with different cereal grains. Thereby, protease activity was mainly cell-associated in Ncm. patriciarum and Piromyces communis, whereas it was predominantly extracellular in Orpinomyces joyonii [116]. Likewise, Paul et al. [112] observed increased ruminal protease activities in buffaloes supplemented with Piromyces FNG5, although it remains unclear whether the increase originated from supplemented fungus or indigenous microbes.

No significant contribution of main ruminal fungi to in situ degradation of soybean cake and meat meal or improvements in the proteolytic activity of rumen fluid through fungi were observed by Bonnemoy et al. [117]. Likewise, Michel et al. [118] stated that rumen fungi have limited abilities to degrade proteins; however, several fungal isolates exerted endo- and exopeptidase activities [118] and may therefore promote ruminal peptidolysis. Additionally, a higher fungal diversity during the increment of protein supply to dairy cows [30] might indicate that ruminal fungi partly benefit from high protein provision.

Besides its metabolic activity, knowledge on the abundance of a microorganism can help to evaluate its contribution and meaning to rumen metabolism. Because previous studies only enumerated total abundances [30], studies quantifying ruminal fungi on a species level or with regard to their metabolic activity are needed. In the past, quantification of rumen fungi via microscopy may have led to erroneous results, as flagellate protozoa can be identified as fungal zoospores [100]. Thus, DNA-based methods targeting the 18S rDNA or internal transcribed spacer 1 [97] represent attractive alternatives for quantification and diversity analysis. Subsequently, fungal DNA amount or copy numbers of internal transcribed spacer 1 can be converted to estimate the fungal biomass in the rumen $[119,120]$.

\section{Interactions among nitrogenous compound- degrading rumen microorganisms}

It is well established that ruminal microorganisms are continuously interacting, but so far these interactions are not fully understood [30]. In the following, relevant interactions between or with the contribution of NCdegrading rumen microorganisms will be reviewed briefly. Basic interactions like interspecies $\mathrm{H}_{2}$ transfer [111] will not be included.

Wallace [42] early showed the existence of reciprocal interactions between $\mathrm{NC}$-degrading rumen microbes, as different proteolytic bacteria grew better in combination than alone, which was ascribed to an increased cooperative hydrolysis or nutritional interdependences. Hyperammonia producing bacteria, both 'classical' [77] and 'new' [83] HAB, depend on proteolytic species that supply AA to them [80,83] as, except one isolate [121], they are unable to hydrolyze proteins to sustain growth. Moreover, $\mathrm{Cl}$. aminophilum and Psc. anaerobius produced much higher amounts of ammonia when grown with peptidolytic P. ruminicola or P. bryantii [122], thus indicating the dependence on peptidolytics.

Interactions between NC-degrading microorganisms are not always beneficial, but can impair other species, e.g. by bacteriocins [123]. For instance, bovicin HC5, a bacteriocin formed by Strep. bovis HC5 catalyzing the potassium efflux from cells, inhibited growth and ammonia release of $\mathrm{Cl}$. aminophilum in pure cultures [124], but also decreased ammonia production of mixed ruminal bacteria in vitro [123]. Strains of B. fibrisolvens produced a variety of bacteriocins including JL5, which suppressed $\mathrm{Cl}$. sticklandii as well as cellulolytic Ruminococcus albus and Ruminococcus flavefaciens [125], which might be explained by the competition for 
carbohydrates. Generally, the formation of as well as sensitivity against bacteriocins seems to be strainspecific $[123,125]$.

Although excessive deamination is regarded as detrimental for efficient $\mathrm{N}$ utilization [126], there is also a need for deaminating bacteria and linkages between cellulolytic and deaminating rumen microbes. As ammonia represents the sole $\mathrm{N}$ source for cellulolytic bacteria [7], deamination is an important process to provide this NC. Branched-chain volatile fatty acids (BCVFA), which are formed during deamination [127], have stimulatory effects on predominant cellulolytic microorganisms and are crucial for their growth [128]. Then again, these deamination processes remove AA that could have promoted growth of cellulolytics [76]. Bacteria like Strep. bovis exert proteolytic activities to gain access to starch granules surrounded by protein matrices [38]. Thus, this also affects nutrient provision of other amylolytic microorganisms, which are not capable of degrading such matrices.

On the other hand, proteolytic bacteria can benefit from fiber degraders, as maximal cell wall protein degradation was observed when proteolytic and cellulolytic bacteria were incubated together. It was hypothesized that potentially degradable proteins are protected by structural polysaccharides and become available for proteolytic microorganisms through cellulose degradation [129]. Thereby, rumen fungi may also play a role, as they degrade cell wall structures [100], and can therefore provide access to actually surrounded proteins.

Protozoa predate bacteria [96] and fungi [100], but by degrading insoluble dietary proteins, protozoa promote the growth of peptidolytic and deaminating bacteria, which utilize peptides and AA from protozoal proteolysis. Thereby, protozoa may enhance the deaminating activity of HAB [9] and thus reduce the efficiency of $\mathrm{N}$ utilization in the rumen by two modes of action: the predation of bacteria and fungi as well as the release of AA into the rumen. Similar patterns of interaction may occur between peptidolytic or deaminating bacteria and proteolytic fungi that release $\mathrm{NC}$ from their protein breakdown [114]. Dehority et al. [130] stated a general negative interaction between fungi and bacteria, as both form inhibitory substances to limit the growth of the other. However, the administration of Piromyces FNG5 caused a 2.5 -fold increase of bacteria in the rumen of buffaloes [112]. Therefore, the existence, type and extent of interaction between fungi and bacteria may be specific for species or even strains [131] and must be evaluated individually.

\section{Manipulating factors on nitrogenous compound- degrading rumen microorganisms}

Several factors influence the rumen microbiota within a ruminant: Age [132], geographical localization, host species [24], breed [133] and diet [24]. Thereby, diet has the strongest influence [24] and is thus of great importance in livestock production.

The meaning of the rumen microbiota with regard to high performance in livestock production was highlighted by the observation that ruminal bacteria communities of steers with higher feed efficiency (defined as "the difference between an animal's actual feed intake and its expected feed requirements for maintenance and growth over a specific test period" [134]) were more similar between individuals and clearly separated from ruminal bacteria communities of inefficient animals [133]. Therefore, a specific rumen microbiota composition may be significant for satisfying performance of animals. Another study [135] indicated the potential of rumen microbes to influence quality characteristics of milk. The scientists observed high correlations between milkfat yield and the Firmicutes to Bacteroidetes ratio, which were still present at the genus level [135]. Both studies emphasize the influence of rumen microorganisms on the host's physiology and thus the meaning of shaping the microbial composition and its activity to improve nutrient and energy use.

Concerning ruminal $\mathrm{N}$ utilization, manipulating the number and activity of NC-degrading microorganisms is of particular importance, especially as ammonia release in the rumen often exceeds its efficient utilization [126] and consequently results in high $\mathrm{N}$ losses and a waste of resources. Attwood et al. [27] stated the importance of altering the abundance of NC-degrading microorganisms as microbial enzymes would be expressed permanently and thus controlling ruminal $\mathrm{NC}$ degradation by affecting enzyme expression could not represent a promising strategy [26]. Bladen et al. [70], in turn, assumed that increased ammonia production was caused by higher deaminase synthesis without alterations in microbial abundances; therefore, influencing enzyme expression would be the better opportunity to control intra-ruminal $\mathrm{N}$ recycling. So far, different approaches have been applied to improve ruminal $\mathrm{N}$ utilization using one of these two strategies and will be discussed in the following.

\section{Diet composition}

\section{Selection of forage species}

When preparing ruminant diets, selection of forage species affects the composition of NC supplied to the rumen [136] and thereby also the ruminal microbiome and efficiency of $\mathrm{N}$ utilization [127]. In the case of legumes, red clover (Trifolium pratense) expresses polyphenol-oxidase (PPO), an enzyme that causes the formation of protein-phenol complexes when plant tissues are damaged [137]. This increases the proportion of ruminally undegraded dietary crude protein (RUP) [138], which is still digestible in the small intestine and thus an 
available $\mathrm{N}$ source for the host. Moreover, red clover phenolic extract inhibited the growth of C. sticklandii cultures in vitro [139], which along with PPO, may increase $\mathrm{N}$ retention in ruminants. The effect of PPO on ruminal proteolysis was demonstrated in vitro, as the inclusion of red clover to timothy grass-based diets lowered the ammonia to insoluble- $\mathrm{N}$ ratio, indicating a limited protein degradation [140]. Likewise, the production of ammonia and i-valerate was lower in fermenters supplied with cocksfoot (Dactylis glomerata), a grass species high in PPO, when compared to fermenters incubated with the low PPO grass species tall fescue (Festuca arundinacea) [141]. Cocksfoot may hence be an important grass species on permanent pasture used for both grazing and silage production. Likewise, red clover may be an attractive legume for arable pasture areas to improve the RUP supply from forage plants.

\section{Synchronization of dietary energy and nitrogen}

Combining different feedstuffs to synchronize the provision of dietary energy and $\mathrm{N}$ [142] may also affect certain groups of NC-degrading microorganisms. In diets containing highly degradable $\mathrm{NC}$ and less rapidly available energy, e.g. water-soluble carbohydrates (WSC), HAB might increase in activity and abundance [143] as they probably benefit from their ability to utilize AA energetically without being dependent on carbohydrates [71, 78, 80, 83].

The effects of synchronization are not consistent in literature [142, 144], but increased microbial $\mathrm{N}$ flow to the duodenum and reduced ruminal ammonia concentration have been reported for the combination of legume silage and grass silage high in WSC [141], thus suggesting less deamination [8] and the direct incorporation of AA into microbial protein [7]. Likewise, microbial $\mathrm{N}$ flow at the duodenum tended to increase with a more synchronous supply of dietary energy and $\mathrm{N}$ to steers, although ruminal ammonia concentration was not reduced [145]. Studies focusing on whether there are also adaptions in the rumen microbiome are lacking, but could reveal possible linkages that help to reduce $\mathrm{N}$ losses from the rumen.

The synchronization of dietary energy and $\mathrm{N}$ could reduce detrimental consequences of high deamination activity from $\mathrm{HAB}$ as it supplies sufficient energy for microbial utilization of ammonia. Secondly, adequate provision of dietary energy may nullify the advantage of $\mathrm{HAB}$ to generate energy from AA. This may reduce their abundance along with long-term alterations of the ruminal microbiota composition and could also explain the predicted 4-fold lower $\mathrm{HAB}$ population in cattle fed high-grain diets compared to hay-fed cattle [81]. Moreover, one can speculate whether HAB capable to ferment carbohydrates [83] shift from AA to carbohydrates as the preferred substrate for energy generation and thus still be present in the rumen but exerting a different metabolic pathway with less deamination.

\section{Application of fats}

Diets containing higher proportions of fats with unsaturated fatty acids, commonly termed oils, are already used to increase the energy supply to ruminants [146]. Although this does not help to cover the energy needs of rumen microbes [147], fat supplementation may influence ruminal $\mathrm{N}$ metabolism [146]. For instance, the addition of $26 \mathrm{~mL} / \mathrm{d}$ of linseed oil to a basal diet for sheep almost eliminated all rumen protozoa and improved the efficiency of bacterial protein synthesis by more than $50 \%$, whereas increasing linseed oil supplementation to $40 \mathrm{~mL} / \mathrm{d}$ showed no effect on the efficiency of bacterial protein synthesis [148]. Other studies even reported the increased abundance of proteolytic bacteria and the increased formation of ammonia when feeding linseed or soybean oil to dairy cows [149]. Therefore, the effects of fat supplementation on NC-degrading microorganisms seem to be variable and difficult to predict. Besides, detrimental impacts like reduced ruminal degradation of organic matter [148] or hemicelluloses [147] and subsequently less availability of dietary energy in the rumen, were repeatedly documented for oil supplementation. This can be explained by the general toxicity of unsaturated fatty acids on rumen microorganisms [147] and might outweigh the positive impact on intraruminal $\mathrm{N}$ recycling.

\section{Feed treatment \\ Wilting}

Wilting forages is an efficient way to reduce energy losses during ensiling [150], but also influences the composition of NC in silages [151, 152]. Both may affect ruminal NC-degrading microorganisms via variation in the energy supply [152] and differing percentages of true protein in silages [151], thereby influencing the quality of $\mathrm{N}$ supply to the rumen. Fast wilted silages have higher true protein contents and lower ruminal ammonia concentrations during in vitro and higher RUP values during in situ incubation [151]. Likewise, grass silages with high contents of free AA (>300 mmol/kg dry matter) and less true protein resulted in higher concentrations of ammonia and BCVFA along with a lower efficiency of $\mathrm{N}$ assimilation into microbial protein by liquid-associated bacteria in vitro [143].

In grass silages, wilting also increased WSC [150, 152], which can enhance microbial protein synthesis in the rumen by a higher provision of dietary energy [153]. Interestingly, wilting is assumed to promote PPO activity in red clover [137], thereby increasing RUP by forming phenol-bound proteins [138]. However, no enhanced PPO activity was obtained when wilting cocksfoot [154] 
suggesting that effects on PPO activity depend on plant species. To the best of the authors' knowledge, there is a lack of research on the effect of differently wilted forages on the ruminal microbiota composition. So far, only microbial metabolite productions have been investigated, but comprehensive experiments analyzing both microbial abundances and metabolites are indispensable to optimize forage conservation in the future.

\section{Organic acid treatment}

Influencing the ruminal microbiome by processing feedstuffs with organic acids was found to be an effective option during recent years [22]. Acids alter the solubility and protein structure, thereby affecting the quantity and quality of $\mathrm{N}$ supplied to the rumen [155]. Barley treated with lactic acid reduced BCVFA concentration in vitro $[22,68]$, but did not affect ammonia concentration [22]. Deckardt et al. [22] concluded a decreased AA catabolism, although addition of lactic acid did not affect the abundance of M. elsdenii or other NC-degrading microorganisms like Prevotella or Entodinium. Besides, fiber degradation was enhanced in acid-treated barley [22], which emphasizes the benefit of processing concentrate with organic acids. Concerning the degradation of soybean meal protein, treatment with $5 \%$ propionate reduced proteolysis as well as numerical concentrations of ammonia and i-valerate in vitro [155], indicating reduced metabolic activities of proteolytic and deaminating microorganisms $[127,143]$. Manipulating the structure and solubility of proteins through acid treatment seems to be a feasible approach to alter the cascade of NC breakdown in the rumen. Together with the observations for fiber degradation, findings so far give evidence for an improved $\mathrm{N}$ retention, which should be pursued in further studies addressing total $\mathrm{N}$ flows.

\section{Heat treatment}

Heat treatment constitutes a further option to affect ruminal $\mathrm{N}$ metabolism. Treating barley grain with $55{ }^{\circ} \mathrm{C}$ for $48 \mathrm{~h}$ decreased protein degradation, the concentration of i-valerate as well as the abundance of Prevotella and total protozoa in vitro. However, the degradation of organic matter was also lowered [22]. Extensive heat treatments should be applied carefully, as exposing rapeseed meal to $130{ }^{\circ} \mathrm{C}$ or $140{ }^{\circ} \mathrm{C}$ for five minutes led to high RUP contents, but the $140{ }^{\circ} \mathrm{C}$ treatment also caused poor intestinal protein digestibility [156]. Thus, N becomes unavailable for the rumen microbiota and the host, leading to unnecessary $\mathrm{N}$ losses and environmental pollution. Duration and intensity are decisive for the effect of heat treatments on $\mathrm{NC}$ and thereby determine whether they improve $\mathrm{N}$ utilization in ruminants or actually cause the opposite result.

\section{Feed additives}

\section{Plant bioactive lipid compounds}

Plant bioactive lipid compounds (PBLC), commonly but misleadingly termed 'essential oils' [157], are secondary plant metabolites that are not necessary for plant growth and characterized by a vast diversity [158]. So far, a variety of PBLC has been shown to reduce ruminal methane production [159], but also to affect NC-degrading microorganisms by microbicidal or microbiostatic effects [8].

Reduced deamination as well as concentrations of ammonia $[8,159,160]$ and BCVFA were observed with PBLC supplementation in vitro $[8,159]$. Application would hence mean an effective dietary strategy to prevent inefficient $\mathrm{N}$ utilization by ruminants. However, PBLC do not necessarily decrease ruminal ammonia concentrations or deamination $[8,159,161]$, and can even have opposite effects [161].

Plant bioactive lipid compounds cause substantial alterations in the ruminal microbiota, but it is not clear whether they are suited to shape the NC-degrading microbial population in the rumen. Streptococcus bovis is relatively resistant against a multitude of PBLC including thymol [162], clove oil, origanium oil [8] as well as a commercial blend of PBLC [160]. Ruminobacter amylophilus, B. fibrisolvens and Sel. ruminantium, as well as $P$. bryantii and $P$. ruminicola, were highly sensitive against clove and origanium oil [8]. Likewise, protozoa showed high sensitivities against these two substances $[8,159]$ and also against eucalyptus, garlic and peppermint oil in vitro [159]. Consequently, ruminal peptidolysis and proteolysis may be added to the statement of Calsamiglia et al. [158] that the majority of PBLC could affect ruminal deamination.

Abundances of deaminating bacteria, particularly HAB, were often reduced by PBLC supplementation and may explain reduced ammonia concentrations [160]. Origanium oil decreased 16S rDNA copies of M. elsdenii, $\mathrm{Cl}$. aminophilum and $\mathrm{Cl}$. sticklandii in a bovine rumen fluid-based in vitro system [8] and the PBLC blend of McIntosh et al. [160] inhibited the growth of Cl. sticklandii and Psc. anaerobius pure cultures. However, in contrast, C. aminophilum was not affected by different PBLC blends [160, 163].

The aforementioned results were all obtained during in vitro experiments and thus must be evaluated under in vivo conditions. Thereby, the supplementation form needs to be considered as well, as it can influence the effect on ruminal microorganisms. For instance, $16 \mathrm{~S}$ rDNA copies of Prevotella spp. and $\mathrm{Cl}$. aminophilum declined in sheep fed pelleted rosemary leaves (Rosmarinus officinalis L.), whereas $16 \mathrm{~S}$ rDNA copies of the same species were not affected when sheep received the same dosage as pure 'rosemary essential oil'. The authors suggest that differences in chemical composition between 
the supplementation forms are responsible for the deviating effects [164]. Also, 'rosemary essential oil' might not have emulsified properly with the rumen fluid and lacked effectiveness as it floated on top.

Generally, the effects on ruminal NC-degrading microorganisms seem to be specific for the applied PBLC. However, contradictory findings between studies investigating the same PBLC $[159,161,163]$ clearly illustrate that the underlying modes of action are poorly understood and a definite statement in this regard is impossible. Consequently, as claimed previously [8], there is an urgent need for systematic studies on PBLC using standardized conditions to obtain reliable knowledge on the effects on ruminal $\mathrm{N}$ metabolism and microorganisms. Hereby, PBLC should also be critically evaluated for their effect on feed digestion, as several PBLC combinations reduced dry matter digestibility in vitro [163].

\section{Condensed tannins}

As Patra et al. [165] have summarized, supplementing ruminant diets with tannins can influence ruminal metabolism and consequently also intra-ruminal $\mathrm{N}$ recycling. In fact, condensed tannins (CT) have protein binding effects at $\mathrm{pH} 3.5-7.0$ [166] leading to reduced proportions of soluble protein in the rumen and probably increased RUP values [106]. In the abomasum and the proximal duodenum, dietary protein would be available for the host due to low $\mathrm{pH}$ values causing the breakdown of these complexes. However, the risk of repeated formation of protein-tannin-complexes or tannin-binding to the host's enzymes in lower gut sections remains present [166].

In pure cultures, bacteria were unable to degrade proteins when incubated with calliandra CT (Calliandra calothyrsus) [121], and a protein-preserving effect of sainfoin CT on ruminal proteolysis was also evident using ovine rumen fluid, as the ammonia to insoluble- $\mathrm{N}$ ratio was lowered [140]. Likewise, quebracho CT reduced ammonia concentration in vitro [167]. All these observations may be explained by two factors: the formation of protein-tannin-complexes $[121,166]$ and morphological alterations of bacterial cell walls [168] suppressing the growth and proteolytic activity of NCdegrading bacteria [121, 168, 169].

On the other hand, as ammonia constitutes the main $\mathrm{N}$ source for cellulolytic bacteria, an excessive tannininduced protein protection bears the risk of ruminal ammonia concentrations below the critical level for sufficient forage digestion [170] and would have adverse effects on the host's supply with dietary energy and nutrients. Besides, CT can directly inhibit ruminal cellulolytic species [170], their cellulase activity [171] or form complexes with lignocellulose [170].
Feeding CT-rich plants often reduces feed intake [31] due to the reduced palatability and lower degradation rates [172]. Thus, by directly feeding CT-rich plants, it may be difficult to achieve tannin concentrations causing adequate protection of dietary protein in the rumen; however, supplementing purified CT extracts to ruminants should be an option to affect ruminal degradation of NC, particularly of proteins. These positive effects must then be weighed carefully against the potential detrimental impact on cellulolytic rumen species.

\section{Saponins}

Besides PBLC and tannins, saponins are a third group of secondary plant metabolites with bioactive functions [158]. Several saponins were evaluated as feed additives in animal nutrition [173-175], but as with PBLC, the results are not consistent. Quillaja saponins (Quillaja saponaria Molina) lowered ammonia concentration by $20 \%$ in vitro, which was probably due to a reduction of protozoal $18 \mathrm{~S}$ rDNA copies [8]. It is assumed that saponins form complexes with sterols in the protozoal membrane surface, which thereby becomes disrupted [176] and leads to cell death. Similarly, Yucca schidigera saponins inhibited protozoal predation and reduced ammonia concentrations in vitro [177]. In contrast to the in vitro data [177], protozoal counts in rumen fluid were not altered, when Yucca schidigera saponin extract was supplemented to dairy cows [173]. Tea saponins, however, reduced ruminal ammonia concentration and protozoal 18S rDNA copies when fed to sheep [174].

The effects of saponins on several NC-degrading bacteria are even less clear. Quillaja saponins increased the $16 \mathrm{~S}$ rDNA copies of $R b$. amylophilus, Sel. ruminantium, P. ruminicola and P. bryantii [8], what was also observed for Prevotella [175] and P. bryantii [177] during in vitro application of Yucca schidigera saponins. In contrast to quillaja saponins [8], Yucca schidigera saponins suppressed the growth of pure cultures of $R b$. amylophilus [178] and also that of B. fibrisolvens [177]. 16S rDNA copies of M. elsdenii and 'classical' HAB [77] were not affected by quillaja saponins, which seems contradictory in view of the reduced ammonia concentration [8]. The authors suggested the decrease of protozoa to be responsible. However, reductions of proteolytic and deaminating bacteria that were not targeted by qPCR, e.g. 'new' HAB [83], could also be causative [8]. Additionally, one can speculate whether saponins have suppressing effects on metabolic activities but not abundances of $\mathrm{NC}$ degrading bacteria.

So far, the use of saponins may be an option to modulate ruminal NC degradation in a beneficial way, but inhibitory effects on protozoa or bacteria seem to depend on dosage as well as saponin type and remain poorly understood [8]. Under practical conditions, 
however, the ability of saponins to reduce feed intake [173] clearly limits their application to dairy diets.

\section{Anacardic acids}

As summarized by Kobayashi et al. [179], anacardic acids predominantly present in the by-products of cashew (Anacardium occidentale) and ginkgo (Ginkgo biloba) nut production, are discussed as modifiers of rumen fermentation. Anacardic acids are characterized as a group of few closely related organic compounds, differing in saturation and side chain length [180]. A first in vitro study investigating the effect of anacardic acid containing ginkgo by-products found decreased concentrations of ammonia, which may be caused by high sensitivities of 'classical' HAB [77] against anacardic acids [181]. However, the effects on other ruminal NCdegrading microbes are less clear and even contradictory in parts. For example, $16 \mathrm{~S}$ rDNA copies of M. elsdenii and Sel. ruminantium increased in vitro when fermenters were supplied with either ginkgo extract [181] or cashew nut shell liquid [182]. 16S rDNA copies of P. ruminicola increased with ginkgo extract [181], but declined when cashew nut shell liquid was added [182]. This inconsistency may be explained by differences in the structure of anacardic acids contained in ginkgo and cashew byproducts [181] or also by the presence of other antimicrobial compounds [179]. As both studies used similar diets for the in vitro incubation as well as bead beatingbased DNA extractions and identical primers for qPCR analysis, laboratory procedures may not have been a contributing factor for the deviating microbial abundances. Therefore, further studies are indispensable to evaluate whether anacardic acids are an option to shape the ruminal NC-degrading microbiota and which structural form is most effective.

\section{Bitter substances}

Although bitter substances were early found to have antimicrobial properties [183], their consideration as modulators of the rumen microbiota is new and scarcely explored. First in vitro investigations by Flythe [184] observed hops flowers (Humulus lupulus L.) and hops extract to inhibit ammonia production in mixed rumen fluid, as well as growth and ammonia production in pure cultures of 'classical' HAB [77]. These suppressing effects are likely caused by humulone and lupulone, which are the main bitter substances in hops, and are also known as $\alpha$-acid and $\beta$-acid, respectively [184]. Additionally, growth of Strep. bovis was inhibited by lupulone when cultivated in pure culture [185]. Likewise, ammonia production in rumen fluid incubated with spent craft brewer's yeast was lower than that with baker's yeast. This supports the assumption that hops bitter substances can decrease ruminal ammonia production and indicate reduced deamination [186].

The target site of humulone and lupulone is the cell membrane's lipophilic region, where they cause membrane leakage and consequently cell death [183]. However, except for 'classical' HAB [77] and Strep. bovis, no information is available regarding their effect on other rumen microorganisms. As the supplementation with two hops cultivars not only decreased in vitro degradability of crude protein by up to $36 \%$, but also degradability of dry matter by up to $33 \%$ [187], inhibiting effects on other parts of the rumen microbiome are likely. Thus, bitter substances like humulone and lupulone could provide an opportunity to affect ruminal $\mathrm{N}$ metabolism in the future; however, sparse knowledge bases on in vitro trials and hitherto an assessment cannot be made.

\section{lonophores}

Since their ban as feed additives in the EU in 2006 [188], ionophores only represent an option in other parts of the world, e.g. North America where ionophores, predominantly monensin, are widely applied in beef production [189]. Ionophores are described as a heterogeneous group of membrane-active molecules impairing transmembrane concentration gradients [190]. Concerning their effect on protozoa, it must be distinguished between short-term and long-term effects. Although naïve protozoal populations were nearly completely eliminated in vitro [16], repeated application of monensin did not have an effect on protozoal cultures [191]. These adaption patterns do also apply for in vivo long-term monensin application [192]. Thus, also decreased ammonia concentrations observed shortly after a monensin-induced protozoa reduction [16] may not last and return to pre-treatment level. This might even be the case if protozoa would stay absent as bacteria proliferating in the absence of protozoa could replace protozoal activity [104].

Although there is no clear-cut difference in the susceptibility against monensin between gram-negative and gram-positive bacteria [193], gram-negative bacteria are generally more resistant [192, 194] due to their outer membrane structure and cell wall constitution [194]. However, also cell flocculation or synthesis of protective extracellular polysaccharides affect the effectiveness of monensin and can occur in both gram-positive and gram-negative bacteria [193]. Thus, future studies should address microbial taxa [195] to provide a superior picture about the monensin susceptibility of NC-degrading microorganisms in the rumen.

The gram-positive 'classical' and 'new' HAB [77, 83] are monensin-sensitive [71, 78, 83] and monensin is undoubtedly effective at reducing deamination [196], 
ammonia concentration and abundances of 'classical' HAB [77] in vitro [16, 160, 196] and in vivo [79, 197].

In vitro application of the ionophore hainamycin decreased 16S rDNA copies of B. fibrisolvens, Cl. sticklandii, $\mathrm{Cl}$. aminophilum and Psc. anaerobius, whereas $M$. elsdenii was unaffected and P. ruminicola increased [198]. Actually, these shifts can be considered beneficial as they were accompanied by decreased ammonia concentration, deaminase activity and proportions of BCVFA in total volatile fatty acids.

Altogether, the aforementioned findings suggest a general ability of ionophores to influence NC-degrading bacteria and underline their potential to reduce ruminal $\mathrm{N}$ wastage. Nonetheless, research on long-term application of ionophores should confirm lasting alterations in abundance and activity of NC-degrading rumen microbes.

\section{Probiotics}

Probiotics are defined as live microorganisms that confer a health benefit on the host by improving its intestinal microbial balance [199] and are widely used in animal nutrition [200]. Applying qPCR, 16S rDNA copies of $R b$. amylophilus and Strep. bovis decreased in steers supplied daily with viable Saccharomyces cerevisiae I-1077 through rumen cannulas. $18 \mathrm{~S}$ or $16 \mathrm{~S}$ rDNA copies of total protozoa and Sel. ruminantium, in turn, increased due to the supplementation [201]. Concerning N metabolism, proteolytic and peptidolytic activities of $P$. albensis, B. fibrisolvens and Strep. bovis decreased during in vitro incubation with viable S. cerevisiae I-1077 [202]. However, despite various alterations on a microbiological level, other studies reported no improvements of the amount and AA composition of microbial $\mathrm{N}$ reaching the duodenum in dairy cows supplemented with live yeast culture of S. cerevisiae [203]. Therefore, comprehensive studies evaluating the effects of S. cerevisiae on ruminal NC-degrading microorganisms are encouraged as probiotic effects seem to be strain-specific [204]. Additionally, the combination of probiotics either with prebiotic substances, leading to so-called synbiotics [200], or with plant extracts (e.g. tannins) could enhance the effects in ruminants [205].

A chance to inhibit AA catabolism through probiotics was indicated by Callaway et al. [196], who found that the L. lactis-derived bacteriocin nisin [206] suppressed deamination and the growth of $\mathrm{Cl}$. aminophilum in vitro. Thus, supplying ruminants with bacteriocinproducing probiotics might particularly alter deamination, but studies on the identification of strains that inhibit growth [205] and activity of HAB are still pending. Because existing data $[123-125,196]$ were only obtained from in vitro experiments, more efforts must be made to evaluate such mechanisms in vivo. However, various interactions with other microbes and the host as well as the general high complexity of the rumen microbiome could make it hardly possible to relate any measured effect to bacteriocins.

To expand the field of probiotic candidates, the transfer of microorganisms from one ruminant species to another might constitute a further option to improve ruminal $\mathrm{N}$ metabolism. Administering a fungal strain from wild blue bull (Boselaphus tragocamelus) to buffaloes (Bubalus bubalis) increased $\mathrm{N}$ retention along with higher protease activity, but equal ammonia concentration [112], indicating a higher breakdown of dietary crude protein but concomitantly enhanced ruminal $\mathrm{N}$ utilization. Besides, the increase of cellulolytic and hemicellulolytic bacteria [112] may have contributed to higher $\mathrm{N}$ retention, as it could lead to a more synchronized fermentation of carbohydrates and NC. It is noteworthy that microbes showing effectiveness in one ruminant species can fail to colonize the rumen of other species as the establishment of exogenously added microorganisms is difficult [67].

\section{Metals}

A variety of metal compounds is added to ruminant diets to meet mineral element requirements [207]. Besides, metal ions have antimicrobial effects and in case of NC-degrading microorganisms iron, copper, tin and chromium decreased bacterial dipeptidase activity by interacting with sulfhydryl groups or by displacing the metal ion from the enzyme [208]. Although iron effectively reduced dipeptidase activity in pure cultures of $P$. albensis [208], the effect may be nullified in rumen fluid as lactobacilli can take up high amounts of iron [209]. Besides the effects on rumen bacteria, Brade et al. [210] described defaunating effects of zinc-enriched diets in the rumen of dairy cows. Likewise, Mihaliková et al. [211] found high sensitivities of En. caudatum cultures against copper and chromium.

Lead, cadmium and mercury also inhibit microbial dipeptidase activity [208], but are irrelevant for controlling ruminal $\mathrm{N}$ metabolism due to the tremendous toxicity to humans and animals [212].

Metal ions are probably not specific to peptide metabolism [208] and therefore impair other ruminal microorganisms as well. Besides, some metals are also not suitable for every host; for example, several sheep breeds have low tolerance levels for copper [213]. Therefore, extensive metal utilization to improve $\mathrm{N}$ utilization in ruminant production is unlikely. This is particularly true as the majority of metals will be excreted via feces when fed in higher concentrations [214], thus only shifting but not mitigating the problem of environmental pollution.

\section{Vaccination}

Vaccination against protozoa has been examined to reduce bacterial predation thereby improving the efficiency 
of $\mathrm{N}$ utilization [215]. Although applied vaccines increased specific immunoglobulins (Ig)G titers in plasma and saliva, they failed to decrease the ruminal ammonia concentration and protozoal counts in vivo. This failure might also be caused by Ig breakdown in the rumen; although $\operatorname{IgG}$ were resistant against degradation for eight hours in vitro [215], the in vivo situation may be different. Analogous to the secretory component of IgA, which conserves this Ig from proteolysis in the gut [216], a protective component may also improve the effect of vaccination against protozoa in the rumen. Though, it should be noted that a general absence of protozoa does not necessarily mean an improvement of ruminal metabolism as, besides their role in bacteria, fungi and NC breakdown, protozoa are also important for sufficient ruminal fiber degradation [109]. Thus, as already claimed [96, 106], it is desirable to inhibit specific protozoal species to improve $\mathrm{N}$ utilization and simultaneously maintain fiber degradation. Future approaches should also concentrate on long-term bacterial-protozoal interactions as bacteria may replace protozoal dipeptidase activity in the rumen [104].

A recent vaccination strategy targets the ruminal breakdown of urea and showed reduced ureolysis and ammonia concentration in vitro when incubating rumen fluid of cows that had been vaccinated against urease. Accordingly, ruminal urease activity decreased by $17 \%$ after vaccination in vivo [86] leading to the assumption that immunization against urease has the potential to control ruminal ureolysis. In this study [86], samples were taken from rumen fluid, but provided that antiurease Ig are not only present in saliva, but also diffuse through the rumen wall, it may be interesting to investigate effects on the epimural ureolytic bacteria, which therefore should be strongly affected. Nevertheless, for evaluating the overall benefit of urea vaccination, effects on total $\mathrm{N}$ utilization must be analyzed, too.

\section{Future perspectives}

This review discussed dietary factors by which ruminal $\mathrm{NC}$ degradation processes and related microorganisms can be influenced in adult animals. As a future perspective, manipulation of the rumen microbiome in young pre-ruminants may become an opportunity to shape ruminal metabolism and microbiota in adult animals. As a specific rumen microbiota composition is associated with improved animal performance, corresponding microbial compositions could be used as inoculum or feed additive in young ruminants to establish a favorable microbiome. Consequently, the adult ruminant may achieve an enhanced performance, not only with regard to energy utilization but also in terms of ruminal $\mathrm{N}$ utilization.
Inhibiting the establishment of only specific microorganisms in the evolving rumen could be a second approach for shaping the rumen microbiota in a more permanent manner. Thereby, other rumen microbes could occupy the niche of inhibited species consequently excluding them from the adult microbiota. Suppressing the colonization of $\mathrm{HAB}$ already in the developing rumen may become a beneficial strategy regarding intraruminal $\mathrm{N}$ recycling.

To investigate such options in the future and for further research on the rumen ecosystem in general, studies employing large sample numbers will be required to overcome the confounding effect of natural animal-toanimal variation and enhance the statistical power of rumen microbiota-related studies. However, the need for cannulated animals considerably limits the broad examination of the rumen microbiome and stomach tubing, the main source for rumen microbiome in many studies, is misleading because it under-represents particleassociated microorganisms. Recent findings indicate that non-invasive regurgitated ingesta samples are suitable for the precise prediction of rumen microbiota compositions [217]. Therefore, this can constitute an appropriate sampling method for determining rumen microbial communities on a large scale. However, phylogenetic information is unable to fully explain all underlying mechanisms or relevant activities of ruminal NCdegrading microorganisms. Thus, besides capturing the microbial composition in the rumen, the concurrent pursuit of a functional classification may be decisive in future to further improve our understanding of intraruminal $\mathrm{N}$ recycling and consequently how to manipulate it beneficially.

\section{Conclusions}

In summary, ruminal NC degradation is not a wasteful process per se, but as ruminal ammonia concentration often exceeds the microorganisms' capacity to incorporate, high $\mathrm{N}$ losses are the consequence. Controlling intra-ruminal $\mathrm{N}$ recycling may not only help improving $\mathrm{N}$ utilization and optimizing ruminant livestock production, but also contributes to a more sustainable agriculture due to less N-containing emissions and lowered resource input. Thereby, the superordinate aim is the sufficient suppression of ruminal NC degradation, particularly deamination, along with maintaining an adequate $\mathrm{N}$ provision for the rumen microbiota to ensure high fiber degradation and host supply with microbial protein. The information on NC-degrading rumen microbes is still very limited and investigations on their phylogenic and functional characterization are far from complete. It is known that ruminal NCdegrading microorganisms mainly belong to bacteria, but also to protozoa and fungi. Bacteria are present at all 
stages of ruminal NC breakdown. Because of high deamination rates, HAB particularly contribute to excessive ruminal ammonia release and subsequent poor $\mathrm{N}$ utilization. So far, these bacteria were assumed to show low abundance in the rumen and to use AA as energy and $\mathrm{N}$ sources, but not carbohydrates. However, recent findings indicate the presence of $\mathrm{HAB}$ able to ferment both AA and carbohydrates. Protozoa are particularly active at degrading insoluble proteins, dipeptides and are responsible for bacterial and fungal predation. The contribution of fungi to ruminal NC degradation is smaller and concentrates on proteo- and peptidolysis. Due to nutritional interdependences and competing demands, NC-degrading microorganisms are continuously interacting with each other and further members of the rumen microbiota. By using different dietary strategies or vaccination, the composition as well as the metabolic activity of NC-degrading microorganisms can be manipulated. Thereby, the targeted composition as well as the treatment of feedstuffs provide promising approaches. Besides, a variety of feed additives including probiotics, condensed tannins or PBLC may constitute effective tools for controlling ruminal $\mathrm{N}$ metabolism. The limited existence and partial inconsistency of results confound the exact evaluation of so far investigated ways to manipulate NC-degrading microorganisms. Beyond that, too many approaches being effective in vitro were not followed up in vivo but this should be undertaken in the future. Thus, systematic and comprehensive studies investigating the composition and metabolism of the rumen microbiome are crucial to obtain a deeper knowledge that will subsequently allow a targeted manipulation. Thereby, omics and qPCR will play a leading role, supported by new developments in sampling techniques.

\footnotetext{
Abbreviations

AA: Amino acid; B.: Butyrivibrio; BCVFA: Branched-chain volatile fatty acids; Cl.: Clostridium; CT: Condensed tannin; En:: Entodinium; Eu.: Eubacterium; HAB: Hyper-ammonia producing bacteria; Ig: Immunoglobulin; L.: Lactobacillus; M.: Megasphaera; N: Nitrogen; NC: Nitrogenous compound; Ncm.: Neocallimastix; NGS: Next-generation sequencing; P.: Prevotella; PBLC: Plant bioactive lipid compound; PPO: Polyphenol oxidase; PsC.: Peptostreptococcus; qPCR: quantitative real-time polymerase chain reaction; Rb:: Ruminobacter; RUP: Rumen-undegraded dietary crude protein; S.: Saccharomyces; Sel.: Selenomonas; Staph: Staphylococcus;

Strep:: Streptococcus; WSC: Water-soluble carbo-hydrates
}

\section{Acknowledgements}

The comments of two anonymous reviewers helped to improve the manuscript and are gratefully acknowledged.

\section{Funding}

This work was supported by the "Deutsche Forschungsgemeinschaft" (DFG, German Research Foundation, SU124/33-1).
Authors' contributions

TH wrote the manuscript. NG and KHS supervised and edited the manuscript. All authors read and approved the final manuscript.

Ethics approval and consent to participate

Not applicable.

Consent for publication

Not applicable.

Competing interests

The authors declare that they have no competing interests.

Received: 14 October 2017 Accepted: 6 March 2018

Published online: 22 April 2018

References

1. Baldwin RL, Allison MJ. Rumen metabolism. J Anim Sci. 1983;57:461-77.

2. Czerkawski JW. An introduction to rumen studies. Oxford: Pergamon Press; 1986

3. Hungate RE. The rumen and its microbes. New York and London: Academic Press; 1966.

4. Piao H, Lachman M, Malfatti S, Sczyrba A, Knierim B, Auer M, et al. Temporal dynamics of fibrolytic and methanogenic rumen microorganisms during in situ incubation of switchgrass determined by $16 \mathrm{~S}$ rRNA gene profiling. Front Microbiol. 2014:5:307. https://doi.org/10.3389/fmicb.2014.00307.

5. Hess M, Sczyrba A, Egan R, Kim T-W, Chokhawala H, Schroth G, et al. Metagenomic discovery of biomass-degrading genes and genomes from cow rumen. Science. 2011;331:463-7. https://doi.org/10.1126/ science.1200387.

6. Tamminga S. Protein degradation in the forestomachs of ruminants. J Anim Sci. 1979;49:1615-30. https://doi.org/10.2527/jas1979.4961615x.

7. Russell JB, O'Connor JD, Fox DG, van Soest PJ, Sniffen CJ. A net carbohydrate and protein system for evaluating cattle diets: I. Ruminal fermentation. J Anim Sci. 1992;70:3551-61.

8. Patra AK, Yu Z. Effects of vanillin, quillaja saponin, and essential oils on in vitro fermentation and protein-degrading microorganisms of the rumen. Appl Microbiol Biotechnol. 2014;98:897-905. https://doi.org/10. 1007/s00253-013-4930-x.

9. Firkins $J$, Yu Z, Morrison M. Ruminal nitrogen metabolism: perspectives for integration of microbiology and nutrition for dairy. J Dairy Sci. 2007;90(E. Suppl):E1-E16. https://doi.org/10.3168/jds.2006-518.

10. Malmuthuge N, Guan LL. Gut microbiome and omics: a new definition to ruminant production and health. Anim Front. 2016;6:8-12. https://doi.org/ 10.2527/af.2016-0017.

11. Chaucheyras-Durand F, Ossa F. Review: the rumen microbiome: composition, abundance, diversity, and new investigative tools. Prof Anim Sci. 2014;30:1-12. https://doi.org/10.15232/S1080-7446(15)30076-0.

12. Khafipour E, Li S, Tun HM, Derakhshani H, Moossavi S, Plaizier JC. Effects of grain feeding on microbiota in the digestive tract of cattle. Anim Front. 2016;6:13-9. https://doi.org/10.2527/af.2016-0018.

13. Rebollar EA, Antwis RE, Becker MH, Belden LK, Bletz MC, Brucker RM, et al. Using "omics" and integrated multi-omics approaches to guide probiotic selection to mitigate chytridiomycosis and other emerging infectious diseases. Front Microbiol. 2016;7:68. https://doi.org/10.3389/ fmicb.2016.00068.

14. Paillard D, McKain N, Rincon MT, Shingfield KJ, Givens DI, Wallace RJ. Quantification of ruminal Clostridium proteoclasticum by real-time PCR using a molecular beacon approach. J Appl Microbiol. 2007;103:1251-61. https:// doi.org/10.1111/j.1365-2672.2007.03349.x.

15. John A, Isaacson HR, Bryant MP. Isolation and characteristics of a ureolytic strain of Selenomonas ruminantium. J Dairy Sci. 1974;57:1003-14. https://doi. org/10.3168/jds.S0022-0302(74)85001-0.

16. Hino T, Russell JB. Relative contributions of ruminal bacteria and protozoa to the degradation of protein in vitro. J Anim Sci. 1987;64:261-70. https:// doi.org/10.2527/jas1987.641261x.

17. Falconer ML, Wallace RJ. Variation in proteinase activities in the rumen. J Appl Microbiol. 1998;84:377-82.

18. Prins RA, van Rheenen DL, van't Klooster AT. Characterization of microbial proteolytic enzymes in the rumen. Antonie Van Leeuwenhoek. 1983;49:585-95. 
19. Newbold CJ, de La Fuente G, Belanche A, Ramos-Morales E, NR ME. The role of ciliate protozoa in the rumen. Front Microbiol. 2015;6:1313. https://doi. org/10.3389/fmicb.2015.01313.

20. Klappenbach JA, Saxman PR, Cole JR, Schmidt TM. Rrndb: the ribosomal RNA operon copy number database. Nucleic Acids Res. 2001;29:181-4.

21. Baldrian $P$, Větrovský $T$, Cajthaml $T$, Dobiášová $P$, Petránková $M$, Šnajdr J, et al. Estimation of fungal biomass in forest litter and soil. Fungal Ecol. 2013; 6:1-11. https://doi.org/10.1016/j.funeco.2012.10.002.

22. Deckardt K, Metzler-Zebeli BU, Zebeli Q. Processing barley grain with lactic acid and tannic acid ameliorates rumen microbial fermentation and degradation of dietary fibre in vitro. J Sci Food Agric. 2016;96:223-31. https://doi.org/10.1002/jsfa.7085.

23. Avguštin $G$, Ramšak A, Peterka M. Systematics and evolution of ruminal species of the genus Prevotella. Folia Microbiol. 2001;46:40-4. https://doi. org/10.1007/BF02825882.

24. Henderson G, Cox F, Ganesh S, Jonker A, Young W, Janssen PH. Rumen microbial community composition varies with diet and host, but a core microbiome is found across a wide geographical range. Sci Rep. 2015;5: 1456. https://doi.org/10.1038/srep14567.

25. Lin C, Raskin L, Stahl DA. Microbial community structure in gastrointestinal tracts of domestic animals: comparative analyses using rRNA-targeted oligonucleotide probes. FEMS Microbiol Ecol. 1997;22:281-94. https://doi. org/10.1111/j.1574-6941.1997.tb00380.x.

26. Wallace RJ, Brammall ML. The role of different species of bacteria in the hydrolysis of protein in the rumen. Microbiology. 1985;131:821-32.

27. Attwood GT, Reilly K. Identification of proteolytic rumen bacteria isolated from New Zealand cattle. J Appl Bacteriol. 1995;79:22-9. https://doi.org/10. 1111/j.1365-2672.1995.tb03119.x.

28. Cotta MA, Hespell RB. Proteolytic activity of the ruminal bacterium Butyrivibrio fibrisolvens. Appl Environ Microbiol. 1986;52:51-8.

29. Attwood GT, Reilly K. Characterization of proteolytic activities of rumen bacterial isolates from forage-fed cattle. J Appl Bacteriol. 1996;81:545-52. https://doi.org/10.1111/j.1365-2672.1996.tb03545.x

30. Belanche A, Doreau M, Edwards JE, Moorby JM, Pinloche E, Newbold CJ. Shifts in the rumen microbiota due to the type of carbohydrate and level of protein ingested by dairy cattle are associated with changes in rumen fermentation. J Nutr. 2012;142:1684-92. https://doi. org/10.3945/jn.112.159574

31. Vasta V, Yáñez-Ruiz DR, Mele M, Serra A, Luciano G, Lanza M, et al. Bacterial and protozoal communities and fatty acid profile in the rumen of sheep fed a diet containing added tannins. Appl Environ Microbiol. 2010;76:2549-55. https://doi.org/10.1128/AEM.02583-09.

32. Hespell RB, Wolf R, Bothast RJ. Fermentation of xylans by Butyrivibrio fibrisolvens and other ruminal bacteria. Appl Environ Microbiol. 1987; 53:2849-53.

33. Reilly K, Attwood GT. Detection of Clostridium proteoclasticum and closely related strains in the rumen by competitive PCR. Appl Environ Microbiol. 1998;64:907-13.

34. Henderson G, Cox F, Kittelmann S, Miri VH, Zethof M, Noel SJ, et al. Effect of DNA extraction methods and sampling techniques on the apparent structure of cow and sheep rumen microbial communities. PLoS One. 2013; 8:e74787. https://doi.org/10.1371/journal.pone.0074787.

35. Kim M, Yu Z. Variations in $16 \mathrm{~S}$ rRNA-based microbiome profiling between pyrosequencing runs and between pyrosequencing facilities. J Microbiol. 2014;52:355-65. https://doi.org/10.1007/s12275-014-3443-3.

36. de Boer R, Peters R, Gierveld S, Schuurman T, Kooistra-Smid M, Savelkoul P. Improved detection of microbial DNA after bead-beating before DNA isolation. J Microbiol Methods. 2010;80:209-11. https://doi.org/10.1016/j. mimet.2009.11.009.

37. Yu Z, Morrison M. Improved extraction of PCR-quality community DNA from digesta and fecal samples. BioTechniques. 2004;36:808-13.

38. Griswold KE, White BA, Mackie RI. Proteolytic activities of the starchfermenting ruminal bacterium, Streptococcus bovis. Curr Microbiol. 1999;39: 180-6. https://doi.org/10.1007/s002849900442.

39. Sales M, Lucas F, Blanchart G. Effects of ammonia and amino acids on the growth and proteolytic activity of three species of rumen bacteria: Prevotella albensis, Butyrivibrio fibrisolvens, and Streptococcus bovis. Curr Microbiol. 2000; 40:380-6. https://doi.org/10.1007/s002840010074.

40. Huws SA, Lee MRF, Muetzel SM, Scott MB, Wallace RJ, Scollan ND. Forage type and fish oil cause shifts in rumen bacterial diversity. FEMS Microbiol Ecol. 2010;73:396-407. https://doi.org/10.1111/j.1574-6941.2010.00892.x.
41. Wallace RJ. Ruminal microbial metabolism of peptides and amino acids. J Nutr. 1996;126:1326-34.

42. Wallace RJ. Synergism between different species of proteolytic rumen bacteria. Curr Microbiol. 1985;12:59-63. https://doi.org/10.1007/BF01567392.

43. Xia $Y$, Kong $Y$, Huang $H$, Yang HE, Forster R, McAllister TA. In situ identification and quantification of protein-hydrolyzing ruminal bacteria associated with the digestion of barley and corn grain. Can J Microbiol. 2016;62:1063-7. https://doi.org/10.1139/cjm-2016-0293.

44. Stiverson J, Morrison M, Yu Z. Populations of select cultured and uncultured bacteria in the rumen of sheep and the effect of diets and ruminal fractions. Int J Microbiol. 2011;2011:750613. https://doi.org/10.1155/2011/750613.

45. Singh KM, Pandya PR, Tripathi AK, Patel GR, Parnerkar S, Kothari RK, et al. Study of rumen metagenome community using qPCR under different diets. Meta Gene. 2014;2:191-9. https://doi.org/10.1016/j.mgene.2014.01.001.

46. Blackburn $\mathrm{TH}$, Hobson PN. Further studies on the isolation of proteolytic bacteria from the sheep rumen. Microbiology. 1962;29:69-81. https://doi. org/10.1099/00221287-29-1-69.

47. Reilly K, Carruthers VR, Attwood GT. Design and use of 165 ribosomal DNA-directed primers in competitive PCRs to enumerate proteolytic bacteria in the rumen. Microb Ecol. 2002;43:259-70. https://doi.org/10. 1007/s00248-001-1052-2.

48. Petri RM, Schwaiger T, Penner GB, Beauchemin KA, Forster RJ, McKinnon JJ, et al. Changes in the rumen epimural bacterial diversity of beef cattle as affected by diet and induced ruminal acidosis. Appl Environ Microbiol. 2013; 79:3744-55. https://doi.org/10.1128/AEM.03983-12.

49. van Gylswyk NO. Enumeration and presumptive identification of some functional groups of bacteria in the rumen of dairy cows fed grass silagebased diets. FEMS Microbiol Lett. 1990;73:243-61. https://doi.org/10.1111/j. 1574-6968.1990.tb03948.x.

50. Jami E, Mizrahi I. Similarity of the ruminal bacteria across individual lactating cows. Anaerobe. 2012;18:338-43. https://doi.org/10.1016/j. anaerobe.2012.04.003.

51. Hazlewood GP, Edwards R. Proteolytic activities of a rumen bacterium, Bacteroides ruminicola R8/4. J Gen Microbiol. 1981;125:11-5. https://doi.org/ 10.1099/00221287-125-1-11.

52. Avguštin G, Wallace RJ, Flint HJ. Phenotypic diversity among ruminal isolates of Prevotella ruminicola: proposal of Prevotella brevis sp. nov., Prevotella bryantii sp. nov., and Prevotella albensis sp. nov. and redefinition of Prevotella ruminicola. Int J Syst Bacteriol. 1997;47:284-8. https://doi.org/10. 1099/00207713-47-2-284

53. Wallace RJ, McKain N. A survey of peptidase activity in rumen bacteria. J Gen Microbiol. 1991;137:2259-64. https://doi.org/10.1099/00221287-137-9-2259.

54. Wallace RJ, McKain N, Broderick GA, Rode LM, Walker ND, Newbold CJ, et al. Peptidases of the rumen bacterium, Prevotella ruminicola. Anaerobe. 1997;3: 35-42. https://doi.org/10.1006/anae.1996.0065.

55. Jami E, Mizrahi I. Composition and similarity of bovine rumen microbiota across individual animals. PLoS One. 2012;7:e33306. https://doi.org/10.1371/ journal.pone.0033306.

56. Rubino F, Carberry C, Waters SM, Kenny D, MS MC, Creevey CJ. Divergent functional isoforms drive niche specialisation for nutrient acquisition and use in rumen microbiome. ISME J. 2017;11:932-44. https://doi.org/10.1038/ ismej.2016.172.

57. Stevenson DM, Weimer PJ. Dominance of Prevotella and low abundance of classical ruminal bacterial species in the bovine rumen revealed by relative quantification real-time PCR. Appl Microbiol Biotechnol. 2007;75:165-74. https://doi.org/10.1007/s00253-006-0802-y.

58. Kim M, Yu Z. Quantitative comparisons of select cultured and uncultured microbial populations in the rumen of cattle fed different diets. J Anim Sci Biotechnol. 2012;3:28. https://doi.org/10.1186/2049-1891-3-28.

59. Tajima K, Aminov RI, Nagamine T, Matsui H, Nakamura M, Benno Y. Dietdependent shifts in the bacterial population of the rumen revealed with real-time PCR. Appl Environ Microbiol. 2001;67:2766-74. https://doi.org/10. 1128/AEM.67.6.2766-2774.2001.

60. del Mar Lleo' M, Tafi MC, Canepari P. Nonculturable Enterococcus faecalis cells are metabolically active and capable of resuming active growth. Syst Appl Microbiol. 1998;21:333-9. https://doi.org/10.1016/S0723-2020(98)80041-6.

61. Walker ND, McEwan NR, Wallace RJ. A pepD-like peptidase from the ruminal bacterium, Prevotella albensis. FEMS Microbiol Lett. 2005;243:399-404. https://doi.org/10.1016/j.femsle.2004.12.032.

62. Wallace RJ, McKain N, Broderick GA. Breakdown of different peptides by Prevotella (Bacteroides) ruminicola and mixed microorganisms from the 
sheep rumen. Curr Microbiol. 1993;26:333-6. https://doi.org/10.1007/ BF01576265.

63. Purushe J, Fouts DE, Morrison M, White BA, Mackie Rl, Coutinho PM, et al. Comparative genome analysis of Prevotella ruminicola and Prevotella bryantii: insights into their environmental niche. Microb Ecol. 2010;60:721-9. https:// doi.org/10.1007/s00248-010-9692-8.

64. Rychlik JL, LaVera R, Russell JB. Amino acid deamination by ruminal Megasphaera elsdenii strains. Curr Microbiol. 2002;45:340-5. https://doi.org/ 10.1007/s00284-002-3743-4.

65. Ouwerkerk D, Klieve AV, Forster RJ. Enumeration of Megasphaera elsdenii in rumen contents by real-time Taq nuclease assay. J Appl Microbiol. 2002;92: 753-8. https://doi.org/10.1046/j.1365-2672.2002.01580.x.

66. Guo TJ, Wang JQ, Bu DP, Liu KL, Wang JP, Li D, et al. Evaluation of the microbial population in ruminal fluid using real time PCR in steers treated with virginiamycin. Czech J Anim Sci. 2010;55:276-85.

67. Weimer PJ, Da Silva CL, Cacite F. Effects of ruminal dosing of Holstein cows with Megasphaera elsdenii on milk fat production, ruminal chemistry, and bacterial strain persistence. J Dairy Sci. 2015;98:8078-92. https://doi.org/10. 3168/jds.2015-9721.

68. Harder H, Khol-Parisini A, Metzler-Zebeli BU, Klevenhusen F, Zebeli Q. Treatment of grain with organic acids at 2 different dietary phosphorus levels modulates ruminal microbial community structure and fermentation patterns in vitro. J Dairy Sci. 2015;98:8107-20. https://doi. org/10.3168/jds.2015-9913.

69. Scheifinger C, Russell N, Chalupa W. Degradation of amino acids by pure cultures of rumen bacteria. J Anim Sci. 1976;43:821-7. https://doi.org/10. 2527/jas1976.434821X.

70. Bladen HA, Bryant MP, Doetsch RN. A study of bacterial species from the rumen which produce ammonia from protein hydrolyzate. Appl Microbiol. 1961;9:175-80

71. Chen G, Russell JB. More monensin-sensitive, ammonia-producing bacteria from the rumen. Appl Environ Microbiol. 1989;55:1052-7.

72. Garner MR, Flint JF, Russell JB. Allisonella histaminiformans gen. Nov., sp. nov. a novel bacterium that produces histamine, utilizes histidine as its sole energy source, and could play a role in bovine and equine laminitis. Syst Appl Microbiol. 2002;25:498-506. https://doi.org/10.1078/ 07232020260517625.

73. Garner MR, Gronquist MR, Russell JB. Nutritional requirements of Allisonella histaminiformans, a ruminal bacterium that decarboxylates histidine and produces histamine. Curr Microbiol. 2004;49:295-9. https://doi.org/10.1007/ s00284-004-4336-1.

74. Yang $\mathrm{S}, \mathrm{Ma} \mathrm{S}$, Chen J, Mao H, He Y, Xi D, et al. Bacterial diversity in the rumen of Gayals (Bos frontalis), swamp buffaloes (Bubalus bubalis) and Holstein cow as revealed by cloned 16S rRNA gene sequences. Mol Biol Rep. 2010;37:2063-73. https://doi.org/10.1007/s11033-009-9664-6.

75. Golder HM, Denman SE, McSweeney C, Celi P, Lean IJ. Ruminal bacterial community shifts in grain-, sugar-, and histidine-challenged dairy heifers. J Dairy Sci. 2014;97:5131-50. https://doi.org/10.3168/jds.2014-8003.

76. Newbold CJ. The need for nitrogen. Br J Nutr. 1999;82:81-2.

77. Paster BJ, Russell JB, Yang CMJ, Chow JM, Woese CR, Tanner R. Phylogeny of the ammonia-producing ruminal bacteria Peptostreptococcus anaerobius, Clostridium sticklandii, and Clostridium aminophilum sp. nov. Int J Syst Bacteriol. 1993:43:107-10.

78. Chen GJ, Russell JB. Fermentation of peptides and amino acids by a monensin-sensitive ruminal Peptostreptococcus. Appl Environ Microbiol. 1988;54:2742-9.

79. Krause DO, Russell JB. An rRNA approach for assessing the role of obligate amino acid-fermenting bacteria in ruminal amino acid deamination. Appl Environ Microbiol. 1996;62:815-21.

80. Attwood GT, Klieve AV, Ouwerkerk D, Patel BKC. Ammoniahyperproducing bacteria from New Zealand ruminants. Appl Environ Microbiol. 1998;64:1796-804.

81. Rychlik JL, Russell JB. Mathematical estimations of hyper-ammonia producing ruminal bacteria and evidence for bacterial antagonism that decreases ruminal ammonia production(1). FEMS Microbiol Ecol. 2000;32: 121-8. https://doi.org/10.1111/j.1574-6941.2000.tb00706.x.

82. Wallace RJ, Chaudhary LC, Miyagawa E, McKain N, Walker ND. Metabolic properties of Eubacterium pyruvativorans, a ruminal 'hyper-ammoniaproducing' anaerobe with metabolic properties analogous to those of Clostridium kluyveri. Microbiology. 2004;150:2921-30. https://doi.org/10.1099/ mic.0.27190-0.
83. Bento C, de Azevedo A, Detmann E, Mantovani H. Biochemical and genetic diversity of carbohydrate-fermenting and obligate amino acid-fermenting hyper-ammonia-producing bacteria from Nellore steers fed tropical forages and supplemented with casein. BMC Microbiol. 2015;15:28. https://doi.org/ 10.1186/s12866-015-0369-9.

84. Whitehead TR, Cotta MA. Isolation and identification of hyperammonia producing bacteria from swine manure storage pits. Curr Microbiol. 2004;48:20-6.

85. Eschenlauer SCP, McKain N, Walker ND, McEwan NR, Newbold CJ, Wallace RJ. Ammonia production by ruminal microorganisms and enumeration, isolation, and characterization of bacteria capable of growth on peptides and amino acids from the sheep rumen. Appl Environ Microbiol. 2002;68: 4925-31. https://doi.org/10.1128/AEM.68.10.4925-4931.2002.

86. Zhao S, Wang J, Zheng N, Bu D, Sun P, Yu Z. Reducing microbial ureolytic activity in the rumen by immunization against urease therein. BMC Vet Res. 2015;11:94. https://doi.org/10.1186/s12917-015-0409-6.

87. Reynolds CK, Kristensen NB. Nitrogen recycling through the gut and the nitrogen economy of ruminants: an asynchronous symbiosis. J Anim Sci. 2007;86:E293-305. https://doi.org/10.2527/jas.2007-0475.

88. Cook AR. Urease activity in the rumen of sheep and the isolation of ureolytic bacteria. J Gen Microbiol. 1976;92:32-48. https://doi.org/10.1099/ $00221287-92-1-32$

89. van Wyk L, Steyn PL. Ureolytic bacteria in sheep rumen. J Gen Microbiol. 1975;91:225-32. https://doi.org/10.1099/00221287-91-2-225.

90. Lu Z, Stumpff F, Deiner C, Rosendahl J, Braun H, Abdoun K, et al. Modulation of sheep ruminal urea transport by ammonia and $\mathrm{pH}$. Am J Physiol Regul Integr Comp Physiol. 2014;307:R558-70. https://doi.org/10. 1152/ajpregu.00107.2014.

91. Cook AR, Riley PW, Murdoch H, Evans PN, McDonald IR. Howardella ureilytica gen. Nov., sp. nov., a gram-positive, coccoid-shaped bacterium from a sheep rumen. Int J Syst Evol Microbiol. 2007;57:2940-5. https://doi. org/10.1099/ijs.0.64819-0.

92. Jin D, Zhao S, Zheng N, Bu D, Beckers Y, Denman SE, et al. Differences in ureolytic bacterial composition between the rumen digesta and rumen wall based on ureC gene classification. Front Microbiol. 2017;8:385. https://doi. org/10.3389/fmicb.2017.00385.

93. Creevey CJ, Kelly WJ, Henderson G, Leahy SC. Determining the culturability of the rumen bacterial microbiome. Microb Biotechnol. 2014;7:467-79. https://doi.org/10.1111/1751-7915.12141.

94. Lockwood BC, Coombs GH, Williams AG. Proteinase activity in rumen ciliate protozoa. J Gen Microbiol. 1988;134:2605-14. https://doi.org/10.1099/ 00221287-134-9-2605.

95. Diaz HL, Barr KN, Godden KR, Plank JE, Zapata I, Schappacher AN, et al. Eukaryotic inhibitors or activators elicit responses to chemosensory compounds by ruminal isotrichid and entodiniomorphid protozoa. J Dairy Sci. 2014;97:2254-69. https://doi.org/10.3168/jds.2013-7698.

96. Belanche A, De La Fuente G, Moorby JM, Newbold CJ. Bacterial protein degradation by different rumen protozoal groups. J Anim Sci. 2012;90:4495504. https://doi.org/10.2527/jas.2012-5118.

97. McSweeney CS, Denman SE, Wright A-DG YZ. Application of recent DNA RNA-based techniques in rumen ecology. Asian-Australas J Anim Sci. 2007; 20:283-94. https://doi.org/10.5713/ajas.2007.283.

98. Kittelmann S, Devente SR, Kirk MR, Seedorf H, Dehority BA, Janssen PH. Phylogeny of intestinal ciliates, including Charonina ventriculi, and comparison of microscopy and $18 \mathrm{~S}$ rRNA gene pyrosequencing for rumen ciliate community structure analysis. Appl Environ Microbiol. 2015;81:243344. https://doi.org/10.1128/AEM.03697-14.

99. Dehority BA. Evaluation of subsampling and fixation procedures used for counting rumen protozoa. Appl Environ Microbiol. 1984;48:182-5.

100. Gordon GLR, Phillips MW. The role of anaerobic gut fungi in ruminants. Nutr Res Rev. 1998;11:133-68. https://doi.org/10.1079/NRR19980009.

101. Williams AG, Coleman GS. The rumen protozoa. New York: Springer; 1992.

102. Ushida K, Jouany JP. Effect of protozoa on rumen protein degradation in sheep. Reprod Nutr Dev. 1985;25:1075-81. https://doi.org/10.1051/rnd:19850807.

103. Coleman GS. Hydrolysis of fraction 1 leaf protein and casein by rumen entodiniomorphid protozoa. J Appl Bacteriol. 1983;55:111-8. https://doi.org/ 10.1111/j.1365-2672.1983.tb02654.X.

104. Newbold CJ, McKain N, Wallace RJ. The role of protozoa in ruminal peptide metabolism. In: Lloyd D, Coombs GH, Paget TAP, editors. Biochemistry and molecular biology of "anaerobic" protozoa. Chur: Harwood Academic Publishers; 1989. p. 42-55. 
105. Diaz HL, Karnati SKR, Lyons MA, Dehority BA, Firkins JL. Chemotaxis toward carbohydrates and peptides by mixed ruminal protozoa when fed, fasted, or incubated with polyunsaturated fatty acids. J Dairy Sci. 2014;97:2231-43. https://doi.org/10.3168/jds.2013-7428.

106. Gresner N, Südekum K-H, Höltershinken M. Umsetzungen von Stickstoffverbindungen des Futters im Pansen. Übers Tierernährg. 2014;42:27-80.

107. Abou Akkada AR, Howard BH. The biochemistry of rumen protozoa: 5 . The nitrogen metabolism of Entodinium. Biochem J. 1962:82:313-20. https://doi. org/10.1042/bj0820313.

108. Forsberg CW, Lovelock LK, Krumholz L, Buchanan-Smith JG. Protease activities of rumen protozoa. Appl Environ Microbiol. 1984;47:101-10.

109. Ivan M, Neill L, Entz T. Ruminal fermentation and duodenal flow following progressive inoculations of fauna-free wethers with major individual species of ciliate protozoa or total fauna. J Anim Sci. 2000;78:750-9.

110. Veira DM, Ivan M, Jui PY. Rumen ciliate protozoa: effects on digestion in the stomach of sheep. J Dairy Sci. 1983;66:1015-22. https://doi.org/10.3168/jds. S0022-0302(83)81896-7.

111. Krause DO, Nagaraja TG, Wright ADG, Callaway TR. Board-invited review: rumen microbiology: leading the way in microbial ecology. J Anim Sci. 2013;91:331-41. https://doi.org/10.2527/jas.2012-5567.

112. Paul SS, Kamra DN, Sastry VRB, Sahu NP, Agarwal N. Effect of administration of an anaerobic gut fungus isolated from wild blue bull (Boselaphus tragocamelus) to buffaloes (Bubalus bubalis) on in vivo ruminal fermentation and digestion of nutrients. Anim Feed Sci Technol. 2004;115:143-57. https:// doi.org/10.1016/j.anifeedsci.2004.01.010.

113. Haitjema CH, Solomon KV, Henske JK, Theodorou MK, O'Malley MA. Anaerobic gut fungi: advances in isolation, culture, and cellulolytic enzyme discovery for biofuel production. Biotechnol Bioeng. 2014;111:1471-82. https://doi.org/10.1002/bit.25264.

114. Wallace RJ, Joblin KN. Proteolytic activity of a rumen anaerobic fungus. FEMS Microbiol Lett. 1985;29:19-25. https://doi.org/10.1111/j.1574-6968. 1985.tb00828.x.

115. Wallace RJ, Munro CA. Influence of the rumen anaerobic fungus Neocallimastix frontalis on the proteolytic activity of a defined mixture of rumen bacteria growing on a solid substrate. Lett Appl Microbiol. 1986;3: 23-6. https://doi.org/10.1111/j.1472-765X.1986.tb01539.x.

116. Yanke $\sqcup$, Dong Y, McAllister TA, Bae HD, Cheng K-J. Comparison of amylolytic and proteolytic activities of ruminal fungi grown on cereal grains. Can J Microbiol. 1993;39:817-20. https://doi.org/10.1139/m93-121.

117. Bonnemoy F, Fonty G, Michel V, Gouet P. Effect of anaerobic fungi on the ruminal proteolysis in gnotobiotic lambs. Reprod Nutr Dev. 1993;33:551-5. https://doi.org/10.1051/rnd:19930606.

118. Michel V, Fonty G, Millet L, Bonnemoy F, Gouet P. In vitro study of the proteolytic activity of rumen anaerobic fungi. FEMS Microbiol Lett. 1993;110: 5-9. https://doi.org/10.1111/j.1574-6968.1993.tb06287.x.

119. Denman SE, MCSweeney CS. Development of a real-time PCR assay for monitoring anaerobic fungal and cellulolytic bacterial populations within the rumen. FEMS Microbiol Ecol. 2006;58:572-82. https://doi.org/10.1111/j. 1574-6941.2006.00190.x.

120. Lwin KO, Hayakawa M, Ban-Tokuda T, Matsui H. Real-time PCR assays for monitoring anaerobic fungal biomass and population size in the rumen. Curr Microbiol. 2011;62:1147-51. https://doi.org/10.1007/s00284-010-9843-7.

121. McSweeney CS, Palmer B, Bunch R, Krause DO. Isolation and characterization of proteolytic ruminal bacteria from sheep and goats fed the tannin-containing shrub legume Calliandra calothyrsus. Appl Environ Microbiol. 1999:65:3075-83.

122. Madeira HM, Peng L, Morrison M. Biochemical and mutational analysis of a gingipain-like peptidase activity from Prevotella ruminicola B(1)4 and its role in ammonia production by ruminal bacteria. Appl Environ Microbiol. 1997;63:670-5.

123. Lima JR, AdO BR, Russell JB, Mantovani HC. Bovicin HC5 inhibits wasteful amino acid degradation by mixed ruminal bacteria in vitro. FEMS Microbiol Lett. 2009;292:78-84. https://doi.org/10.1111/j.1574-6968.2008.01474.x.

124. Mantovani HC, Russell JB. The ability of a bacteriocin of Streptococcus bovis HC5 (bovicin HC5) to inhibit Clostridium aminophilum, an obligate amino acid fermenting bacterium from the rumen. Anaerobe. 2002;8:247-52. https://doi.org/10.1006/anae.2002.0437.

125. Rychlik JL, Russell JB. Bacteriocin-like activity of Butyrivibrio fibrisolvens JL5 and its effect on other ruminal bacteria and ammonia production. Appl Environ Microbiol. 2002;68:1040-6. https://doi.org/10.1128/AEM.68.3.10401046.2002.
126. Annison EF. Nitrogen metabolism in the sheep. Protein digestion in the rumen. Biochem J. 1956;64:705-14. https://doi.org/10.1042/bj0640705.

127. Carro MD, Miller EL. Effect of supplementing a fibre basal diet with different nitrogen forms on ruminal fermentation and microbial growth in an in vitro semi-continuous culture system (RUSITEC). Br J Nutr. 1999;82:149-57. https://doi.org/10.1017/S0007114599001300.

128. Allison MJ, Bryant MP, Doetsch RN. Studies on the metabolic function of branched-chain volatile fatty acids, growth factors for ruminococci I. Incorporation of Isovalerate into leucine. J Bacteriol. 1962;83:523-32.

129. Debroas D, Blanchart G. Interactions between proteolytic and cellulolytic rumen bacteria during hydrolysis of plant cell wall protein. Reprod Nutr Dev. 1993;33:283-8. https://doi.org/10.1051/rnd:19930310.

130. Dehority BA, Tirabasso PA. Antibiosis between ruminal bacteria and ruminal fungi. Appl Environ Microbiol. 2000;66:2921-7.

131. Bernalier A, Fonty G, Gouet P. Cellulose degradation by two rumen anaerobic fungi in monoculture or in coculture with rumen bacteria. Anim Feed Sci Technol. 1991;32:131-6. https://doi.org/10.1016/03778401(91)90016-L.

132. Jami $E$, Israel $A$, Kotser $A$, Mizrahi I. Exploring the bovine rumen bacterial community from birth to adulthood. ISME J. 2013;7:1069-79. https://doi.org/ 10.1038/ismej.2013.2.

133. Guan LL, Nkrumah JD, Basarab JA, Moore SS. Linkage of microbial ecology to phenotype: correlation of rumen microbial ecology to cattle's feed efficiency. FEMS Microbiol Lett. 2008;288:85-91. https://doi.org/10.1111/j. 1574-6968.2008.01343.x

134. Basarab JA, Price MA, Aalhus JL, Okine EK, Snelling WM, Lyle KL. Residual feed intake and body composition in young growing cattle. Can J Anim Sci. 2003;83:189-204. https://doi.org/10.4141/A02-065.

135. Jami E, White BA, Mizrahi I, Heimesaat MM. Potential role of the bovine rumen microbiome in modulating milk composition and feed efficiency. PLoS One. 2014;9:e85423. https://doi.org/10.1371/journal.pone.0085423.

136. Krishnamoorthy U, Muscato TV, Sniffen CJ, van Soest PJ. Nitrogen fractions in selected feedstuffs. J Dairy Sci. 1982;65:217-25. https://doi.org/10.3168/ jds.S0022-0302(82)82180-2.

137. Lee MRF, Tweed JKS, Minchin FR, Winters AL. Red clover polyphenol oxidase: activation, activity and efficacy under grazing. Anim Feed Sci Technol. 2009;149:250-64. https://doi.org/10.1016/j.anifeedsci.2008.06.013.

138. Sullivan ML, Foster JL. Perennial peanut (Arachis glabrata Benth.) contains polyphenol oxidase (PPO) and PPO substrates that can reduce post-harvest proteolysis. J Sci Food Agric. 2013;93:2421-8. https://doi. org/10.1002/jsfa.6050.

139. Flythe M, Kagan I. Antimicrobial effect of red clover (Trifolium pratense) phenolic extract on the ruminal hyper ammonia-producing bacterium, Clostridium sticklandii. Curr Microbiol. 2010;61:125-31. https://doi.org/10. 1007/s00284-010-9586-5.

140. Copani G, Ginane C, Le Morvan A, Niderkorn V. Patterns of in vitro rumen fermentation of silage mixtures including sainfoin and red clover as bioactive legumes. Anim Feed Sci Technol. 2015;208:220-4. https://doi.org/ 10.1016/j.anifeedsci.2015.07.025.

141. Merry RJ, Lee MRF, Davies DR, Dewhurst RJ, Moorby JM, Scollan ND, et al. Effects of high-sugar ryegrass silage and mixtures with red clover silage on ruminant digestion. 1. In vitro and in vivo studies of nitrogen utilization. J Anim Sci. 2006;84:3049-60. https://doi.org/10.2527/jas.2005-735.

142. Hall MB, Huntington GB. Nutrient synchrony: sound in theory, elusive in practice. J Anim Sci. 2007;86:E287-92. https://doi.org/10.2527/jas.2007-0516.

143. Gresner N, Wichern A, Lumpp L, Hoedemaker M, Höltershinken M. Effects of grass silages with two levels of free amino acids on degradation of amino acids and fixation of nitrogen in bacterial protein in bovine ruminal fluid using the rumen simulation technique (Rusitec). Anim Feed Sci Technol. 2015;202:1-11. https://doi.org/10.1016/j.anifeedsci.2014.12.012.

144. Cabrita ARJ, Dewhurst RJ, Abreu JMF, Fonseca AJM. Evaluation of the effects of synchronising the availability of $\mathrm{N}$ and energy on rumen function and production responses of dairy cows-a review. Anim Res. 2006;55:1-24. https://doi.org/10.1051/animres:2005045.

145. Chumpawadee S, Sommart K, Vongpralub T, Pattarajinda V. Effects of synchronizing the rate of dietary energy and nitrogen release on ruminal fermentation, microbial protein synthesis, blood urea nitrogen and nutrient digestibility in beef cattle. Asian-Australas J Anim Sci. 2006;19:181-8. https:// doi.org/10.5713/ajas.2006.181.

146. Stern MD, Varga GA, Clark JH, Firkins JL, Huber JT, Palmquist DL. Evaluation of chemical and physical properties of feeds that affect protein metabolism 
in the rumen. J Dairy Sci. 1994;77:2762-86. https://doi.org/10.3168/jds. S0022-0302(94)77219-2.

147. Broudiscou L, Pochet S, Poncet C. Effect of linseed oil supplementation on feed degradation and microbial synthesis in the rumen of ciliate-free and refaunated sheep. Anim Feed Sci Technol. 1994;49:189-202. https://doi.org/ 10.1016/0377-8401(94)90045-0.

148. Ikwuegbu OA, Sutton JD. The effect of varying the amount of linseed oil supplementation on rumen metabolism in sheep. Br J Nutr. 1982;48:365-75. https://doi.org/10.1079/BJN19820120.

149. Yang SL, Bu DP, Wang JQ, Hu ZY, Li D, Wei HY, et al. Soybean oil and linseed oil supplementation affect profiles of ruminal microorganisms in dairy cows. Animal. 2009;3:1562-9. https://doi.org/10.1017/S1751731109990462.

150. Yahaya MS, Kawai M, Takahashi J, Matsuoka S. The effect of different moisture contents at ensiling on silo degradation and digestibility of structural carbohydrates of orchardgrass. Anim Feed Sci Technol. 2002;101: 127-33. https://doi.org/10.1016/50377-8401(02)00080-9.

151. Edmunds B, Spiekers H, Südekum K-H, Nussbaum H, Schwarz FJ, Bennett R. Effect of extent and rate of wilting on nitrogen components of grass silage. Grass Forage Sci. 2014;69:140-52. https://doi.org/10.1111/gfs.12013.

152. Nguyen HV, Kawai M, Takahashi J, Matsuoka S. Change in nitrogen fractions and ruminal nitrogen degradability of orchardgrass ensiled at various moisture contents and the subsequent effects on nitrogen utilization by sheep. AsianAustralas J Anim Sci. 2005;18:1267-72. https:/doi.org/10.5713/ajas.2005.1267.

153. Lee MRF, Merry RJ, Davies DR, Moorby JM, Humphreys MO, Theodorou MK, et al. Effect of increasing availability of water-soluble carbohydrates on in vitro rumen fermentation. Anim Feed Sci Technol. 2003;104:59-70. https://doi.org/10.1016/50377-8401(02)00319-X.

154. Lee MRF, Cabiddu A, Hou F, Niderkorn V, Kim EJ, Fychan R, et al. In vitro rumen simulated (RUSITEC) metabolism of freshly cut or wilted grasses with contrasting polyphenol oxidase activities. Grass Forage Sci. 2011;66:196-205. https://doi.org/10.1111/j.1365-2494.2010.00775.x.

155. Waltz DM, Stern MD. Evaluation of various methods for protecting soyabean protein from degradation by rumen bacteria. Anim Feed Sci Technol. 1989;25:111-22. https://doi.org/10.1016/0377-8401(89)90112-0.

156. Dakowski P, Weisbjerg MR, Hvelplund T. The effect of temperature during processing of rape seed meal on amino acid degradation in the rumen and digestion in the intestine. Anim Feed Sci Technol. 1996;58:213-26. https:// doi.org/10.1016/0377-8401(95)00868-3.

157. Hausmann J, Deiner C, Immig I, Pieper R, Starke A, Aschenbach JR. Effects of combined supplementation with plant bioactive lipid compounds and biotin on ruminal fermentation, body condition and energy metabolism in transition dairy cows. Anim Feed Sci Technol. 2017;225:27-37. https://doi. org/10.1016/j.anifeedsci.2017.01.009.

158. Calsamiglia S, Busquet M, Cardozo PW, Castillejos L, Ferret A. Invited review: essential oils as modifiers of rumen microbial fermentation. J Dairy Sci. 2007; 90:2580-95. https://doi.org/10.3168/jds.2006-644.

159. Patra AK, Yu Z. Effects of essential oils on methane production and fermentation by, and abundance and diversity of, rumen microbial populations. Appl Environ Microbiol. 2012;78:4271-80. https://doi.org/10 1128/AEM.00309-12.

160. Mclntosh FM, Williams P, Losa R, Wallace RJ, Beever DA, Newbold CJ. Effects of essential oils on ruminal microorganisms and their protein metabolism. Appl Environ Microbiol. 2003;69:5011-4. https://doi.org/10.1128/AEM.69.8. 5011-5014.2003.

161. Chaves AV, He ML, Yang WZ, Hristov AN, McAllister TA, Benchaar C. Effects of essential oils on proteolytic, deaminative and methanogenic activities of mixed ruminal bacteria. Can J Anim Sci. 2008;88:117-22. https://doi.org/10. 4141/CJAS07061.

162. Evans JD, Martin SA. Effects of thymol on ruminal microorganisms. Curr Microbiol. 2000:41:336-40. https://doi.org/10.1007/s002840010145.

163. Cobellis G, Trabalza-Marinucci M, Marcotullio MC, Yu Z. Evaluation of different essential oils in modulating methane and ammonia production, rumen fermentation, and rumen bacteria in vitro. Anim Feed Sci Technol. 2016;215:25-36. https://doi.org/10.1016/.anifeedsci.2016.02.008.

164. Cobellis G, Yu Z, Forte C, Acuti G, Trabalza-Marinucci M. Dietary supplementation of Rosmarinus officinalis $L$. leaves in sheep affects the abundance of rumen methanogens and other microbial populations. J Anim Sci Biotechnol. 2016;7:27. https://doi.org/10.1186/s40104-016-0086-8.

165. Patra AK, Saxena J. Exploitation of dietary tannins to improve rumen metabolism and ruminant nutrition. J Sci Food Agric. 2011;91:24-37. https:// doi.org/10.1002/jsfa.4152.
166. Jones WT, Mangan JL. Complexes of the condensed tannins of sainfoin (Onobrychis viciifolia scop.) with fraction 1 leaf protein and with submaxillary mucoprotein, and their reversal by polyethylene glycol and pH. J Sci Food Agric. 1977;28:126-36. https://doi.org/10.1002/jsfa.2740280204.

167. Makkar HPS, Becker K, Abel HJ, Szegletti C. Degradation of condensed tannins by rumen microbes exposed to Quebracho tannins (QT) in rumen simulation technique (RUSITEC) and effects of QT on fermentative processes in the RUSITEC. J Sci Food Agric. 1995;69:495-500. https://doi.org/10.1002/ jsfa.2740690414.

168. Jones GA, McAllister TA, Muir AD, Cheng K-J. Effects of sainfoin (Onobrychis vicifolia Scop.) condensed tannins on growth and proteolysis by four strains of ruminal bacteria. Appl Environ Microbiol. 1994;60:1374-8.

169. Min BR, Attwood GT, McNabb WC, Molan AL, Barry TN. The effect of condensed tannins from Lotus corniculatus on the proteolytic activities and growth of rumen bacteria. Anim Feed Sci Technol. 2005;121:45-58. https:// doi.org/10.1016/j.anifeedsci.2005.02.007.

170. McSweeney CS, Palmer B, McNeill DM, Krause DO. Microbial interactions with tannins: nutritional consequences for ruminants. Anim Feed Sci Technol. 2001;91:83-93. https://doi.org/10.1016/S0377-8401(01)00232-2.

171. Griffiths DW, Jones DIH. Cellulase inhibition by tannins in the testa of field beans (Vicia faba). J Sci Food Agric. 1977;28:983-9. https://doi.org/10.1002/ jsfa.2740281106.

172. Makkar HPS, Blümmel M, Becker K. In vitro effects of and interactions between tannins and saponins and fate of tannins in the rumen. J Sci Food Agric. 1995;69:481-93. https://doi.org/10.1002/jsfa.2740690413.

173. Benchaar C, McAllister TA, Chouinard PY. Digestion, ruminal fermentation, ciliate protozoal populations, and milk production from dairy cows fed cinnamaldehyde, quebracho condensed tannin, or Yucca schidigera saponin extracts. J Dairy Sci. 2008;91:4765-77. https://doi.org/10.3168/jds.2008-1338.

174. Zhou YY, Mao HL, Jiang F, Wang JK, Liu JX, McSweeney CS. Inhibition of rumen methanogenesis by tea saponins with reference to fermentation pattern and microbial communities in Hu sheep. Anim Feed Sci Technol. 2011;166-167:93-100. https://doi.org/10.1016/j.anifeedsci.2011.04.007.

175. Patra AK, Stiverson J, Yu Z. Effects of quillaja and yucca saponins on communities and select populations of rumen bacteria and archaea, and fermentation in vitro. J Appl Microbiol. 2012;113:1329-40. https://doi.org/10. 1111/j.1365-2672.2012.05440.x.

176. Wallace RJ, McEwan NR, McIntosh FM, Teferedegne B, Newbold CJ. Natural products as manipulators of rumen fermentation. Asian-Australas I Anim Sci. 2002;15:1458-68. https://doi.org/10.5713/ajas.2002.1458.

177. Wallace RJ, Arthaud L, Newbold CJ. Influence of Yucca shidigera extract on ruminal ammonia concentrations and ruminal microorganisms. Appl Environ Microbiol. 1994;60:1762-7.

178. Wang Y, McAllister TA, Yanke $L$, Cheeke PR. Effect of steroidal saponin from Yucca schidigera extract on ruminal microbes. J Appl Microbiol. 2000;88:88796. https://doi.org/10.1046/j.1365-2672.2000.01054.x.

179. Kobayashi Y, Oh S, Myint H, Koike S. Use of Asian selected agricultural byproducts to modulate rumen microbes and fermentation. J Anim Sci Biotechnol. 2016;7:70. https://doi.org/10.1186/s40104-016-0126-4.

180. Hemshekhar M, Sebastin Santhosh M, Kemparaju K, Girish KS. Emerging roles of anacardic acid and its derivatives: a pharmacological overview. Basic Clin Pharmacol Toxicol. 2012;110:122-32. https://doi.org/10.1111/j.17427843.2011.00833.x.

181. Oh S, Shintani R, Koike S, Kobayashi Y. Ginkgo fruit extract as an additive to modify rumen microbiota and fermentation and to mitigate methane production. J Dairy Sci. 2017;100(3):1923-34. https://doi.org/10.3168/jds.2016-11928.

182. Watanabe Y, Suzuki R, Koike S, Nagashima K, Mochizuki M, Forster RJ, et al. In vitro evaluation of cashew nut shell liquid as a methane-inhibiting and propionate-enhancing agent for ruminants. J Dairy Sci. 2010;93:5258-67. https://doi.org/10.3168/jds.2009-2754.

183. Schmalreck AF, Teuber M, Reininger W, Hartl A. Structural features determining the antibiotic potencies of natural and synthetic hop bitter resins, their precursors and derivatives. Can J Microbiol. 1975;21:205-12. https://doi.org/10.1139/m75-029.

184. Flythe MD. The antimicrobial effects of hops (Humulus lupulus L.) on ruminal hyper ammonia-producing bacteria. Lett Appl Microbiol. 2009;48:712-7. https://doi.org/10.1111/j.1472-765X.2009.02600.x.

185. Harlow BE, Lawrence LM, Kagan IA, Flythe MD. Inhibition of fructanfermenting equine faecal bacteria and Streptococcus bovis by hops (Humulus lupulus L.) B-acid. J Appl Microbiol. 2014;117:329-39. https://doi. org/10.1111/jam.12532. 
186. Harlow BE, Bryant RW, Cohen SD, O'Connell SP, Flythe MD. Degradation of spent craft brewer's yeast by caprine rumen hyper ammonia-producing bacteria. Lett Appl Microbiol. 2016;63:307-12. https://doi.org/10.1111/lam.12623.

187. Lavrenčič A, Levart A, Košir IJ, Cerenak A. Influence of two hop (Humulus lupulus L.) varieties on in vitro dry matter and crude protein degradability and digestibility in ruminants. J Sci Food Agric. 2014;94:1248-52. https://doi. org/10.1002/jsfa.6407.

188. European Parliament and Council. Regulation (EC) no. 1831/2003 of the European Parliament and of the council of 22 September 2003 on additives for use in animal nutrition. Off J Eur Union. 2003;L 268:29-43.

189. Yang WZ, Xu L, Zhao YL, Chen LY, McAllister TA. Impact of hard vs. soft wheat and monensin level on rumen acidosis in feedlot heifers. J Anim Sci. 2014;92:5088-98. https://doi.org/10.2527/jas.2014-8092.

190. Ovchinnikov YA. Physico-chemical basis of ion transport through biological membranes: Ionophores and ion channels. Eur J Biochem. 1979;94:321-36. https://doi.org/10.1111/j.1432-1033.1979.tb12898.x.

191. Sylvester JT, SKR K, Dehority BA, Morrison M, Smith GL, St-Pierre NR, et al. Rumen ciliated protozoa decrease generation time and adjust 185 ribosomal DNA copies to adapt to decreased transfer interval, starvation, and monensin. J Dairy Sci. 2009;92:256-69. https://doi.org/10.3168/jds.2008-1417.

192. Firkins JL, Yu Z. Ruminant nutrition symposium: how to use data on the rumen microbiome to improve our understanding of ruminant nutrition. J Anim Sci. 2015;93:1450-70. https://doi.org/10.2527/jas.2014-8754.

193. Weimer PJ, Stevenson DM, Mertens DR, Thomas EE. Effect of monensin feeding and withdrawal on populations of individual bacterial species in the rumen of lactating dairy cows fed high-starch rations. Appl Microbiol Biotechnol. 2008:80:135-45. https://doi.org/10.1007/s00253-008-1528-9.

194. Russell JB, Strobel HJ. Effects of additives on in vitro ruminal fermentation: a comparison of monensin and bacitracin, another gram-positive antibiotic. J Anim Sci. 1988;66:552-8. https://doi.org/10.2134/jas1988.662552x.

195. Kim M, Eastridge ML, Yu Z. Investigation of ruminal bacterial diversity in dairy cattle fed supplementary monensin alone and in combination with fat, using pyrosequencing analysis. Can J Microbiol. 2014;60:65-71. https:// doi.org/10.1139/cjm-2013-0746

196. Callaway TR, Carneiro De Melo AMS, Russell JB. The effect of nisin and monensin on ruminal fermentations in vitro. Curr Microbiol. 1997;35:90-6. https://doi.org/10.1007/s002849900218.

197. Yang CM, Russell JB. The effect of monensin supplementation on ruminal ammonia accumulation in vivo and the numbers of amino acid-fermenting bacteria. J Anim Sci. 1993;71:3470-6. https://doi.org/10.2527/1993.71123470x.

198. Wang ZB, Xin HS, Wang MJ, Li ZY, Qu YL, Miao SJ, et al. Effects of dietary supplementation with hainanmycin on protein degradation and populations of ammonia-producing bacteria in vitro. Asian-Australas J Anim Sci. 2013;26:668-74. https://doi.org/10.5713/ajas.2012.12589.

199. Fuller R. Probiotics in man and animals. J Appl Bacteriol. 1989;66:365-78. https://doi.org/10.1111/j.1365-2672.1989.tb05105.x.

200. Callaway TR, Edrington TS, Anderson RC, Harvey RB, Genovese KJ, Kennedy $\mathrm{CN}$, et al. Probiotics, prebiotics and competitive exclusion for prophylaxis against bacterial disease. Anim Health Res Rev. 2008;9:217-25. https://doi. org/10.1017/S1466252308001540.

201. Ding G, Chang Y, Zhao L, Zhou Z, Ren L, Meng Q. Effect of Saccharomyces cerevisiae on alfalfa nutrient degradation characteristics and rumen microbial populations of steers fed diets with different concentrate-toforage ratios. J Anim Sci Biotechnol. 2014;5:24-32. https://doi.org/10.1186/ 2049-1891-5-24

202. Chaucheyras-Durand F, Masseglia S, Fonty G. Effect of the microbial feed additive Saccharomyces cerevisiae CNCM I-1077 on protein and peptide degrading activities of rumen bacteria grown in vitro. Curr Microbiol. 2005; 50:96-101. https://doi.org/10.1007/s00284-004-4433-1.

203. Putnam DE, Schwab CG, Socha MT, Whitehouse NL, Kierstead NA Garthwaite BD. Effect of yeast culture in the diets of early lactation dairy cows on ruminal fermentation and passage of nitrogen fractions and amino acids to the small intestine. J Dairy Sci. 1997;80:374-84. https://doi.org/10. 3168/jds.S0022-0302(97)75947-2.

204. Newbold CJ, Wallace RJ, Chen XB, McIntosh FM. Different strains of Saccharomyces cerevisiae differ in their effects on ruminal bacterial numbers in vitro and in sheep. J Anim Sci. 1995;73:1811-8. https://doi.org/10.2527/ 1995.7361811x.

205. Chaucheyras-Durand F, Walker ND, Bach A. Effects of active dry yeasts on the rumen microbial ecosystem: past, present and future. Anim Feed Sci Technol. 2008;145:5-26. https://doi.org/10.1016/j.anifeedsci.2007.04.019.
206. Hansen JN. Nisin as a model food preservative. Crit Rev Food Sci Nutr. 1994; 34:69-93. https://doi.org/10.1080/10408399409527650.

207. McDowell LR. Feeding minerals to cattle on pasture. Anim Feed Sci Technol. 1996:60:247-71. https://doi.org/10.1016/0377-8401(96)00983-2.

208. Wallace RJ, McKain N. Influence of 1,10-phenanthroline and its analogues, other chelators and transition metal ions on dipeptidase activity of the rumen bacterium, Prevotella ruminicola. J Appl Microbiol. 1996;81:42-7. https://doi.org/10.1111/j.1365-2672.1996.tb03280.x.

209. Kot E, Furmanov S, Bezkorovainy A. Accumulation of iron in lactic acid bacteria and bifidobacteria. J Food Sci. 1995;60:547-50. https://doi.org/10. 1111/j.1365-2621.1995.tb09823.x.

210. Brade W, Distl O. Das ruminale Mikrobiom des Rindes (3. Teil). Berichte über Landwirtschaft - Zeitschrift für Agrarpolitik und Landwirtschaft. 2015;93:1-12. https://doi.org/10.12767/buel.v93i3.71.g214.

211. Mihaliková K, Váradyová Z, Pristaš $P$, Javorský $P$, Kišidayová S. Tolerance of a ruminant ciliate Entodinium caudatum against mercury, copper and chromium. Biologia. 2009;64:1141-5. https://doi.org/10. 2478/s11756-009-0189-1.

212. Neathery MW, Miller WJ. Metabolism and toxicity of cadmium, mercury, and lead in animals: a review. J Dairy Sci. 1975;58:1767-81. https://doi.org/10. 3168/jds.S0022-0302(75)84785-0.

213. Woolliams JA, Suttle NF, Wiener G, Field AC, Woolliams C. The effect of breed of sire on the accumulation of copper in lambs, with particular reference to copper toxicity. Anim Prod. 1982;35:299-307. https://doi.org/10. 1017/S0003356100000969.

214. Roggeman S, van den Brink N, van Praet N, Blust R, Bervoets L. Metal exposure and accumulation patterns in free-range cows (Bos taurus) in a contaminated natural area: influence of spatial and social behavior. Environ Pollut. 2013;172:186-99. https://doi.org/10.1016/j.envpol.2012.09.006.

215. Williams YJ, Rea SM, Popovski S, Pimm CL, Williams AJ, Toovey AF, et al. Reponses of sheep to a vaccination of entodinial or mixed rumen protozoal antigens to reduce rumen protozoal numbers. Br J Nutr. 2008;99(1):100-9. https://doi.org/10.1017/S0007114507801553.

216. Lindh $E$. Increased resistance of immunoglobulin a dimers to proteolytic degradation after binding of secretory component. J Immunol. 1975;114:284-6.

217. Tapio I, Shingfield KJ, McKain N, Bonin A, Fischer D, Bayat AR, et al. Oral samples as non-invasive proxies for assessing the composition of the rumen microbial community. PLoS One. 2016;11:e0151220. https://doi.org/10.1371/ journal.pone.0151220.

218. Bach A, Calsamiglia S, Stern MD. Nitrogen metabolism in the rumen. J Dairy Sci. 2005;88(E. Suppl):E9-E21. https://doi.org/10.3168/jds.S00220302(05)73133-7.

\section{Submit your next manuscript to BioMed Central and we will help you at every step:}

- We accept pre-submission inquiries

- Our selector tool helps you to find the most relevant journal

- We provide round the clock customer support

- Convenient online submission

- Thorough peer review

- Inclusion in PubMed and all major indexing services

- Maximum visibility for your research

Submit your manuscript at www.biomedcentral.com/submit
Biomed Central 